\title{
Ajuste oclusal na Ortodontia: por que, quando e como?
}

\author{
Roberto Carlos Bodart Brandão*, Larissa Bustamante Capucho Brandão**
}

\begin{abstract}
Resumo
Introdução: o conhecimento sobre oclusão dentária deve ser considerado condição fundamental para a prática de uma Ortodontia de qualidade. O diagnóstico feito sem a manipulação do paciente em Relação Cêntrica pode levar à surpresa desagradável de se planejar o tratamento de uma má oclusão e se deparar com outra, depois dos primeiros arcos de nivelamento. Ao usar arcos retangulares, é importante a checagem dos contatos oclusais para se definir o tipo de movimento dentário necessário para o alcance do equilíbrio oclusal e, principalmente, verificar se este movimento é exeqüível. Durante o tratamento ortodôntico, devido à complexidade das superfícies oclusais, o ajuste oclusal por desgaste deve ser realizado para viabilizar movimentos dentários verticais, reduzindo o tempo de tratamento. Interferências oclusais são responsáveis tanto por efeitos adversos na biomecânica, quanto por aplicação de forças excessivas, que podem causar reabsorções radiculares. Após a Ortodontia, o ajuste oclusal é um dos determinantes da estabilização dentária, devendo-se obter, para cada dente posterior, contatos oclusais "A" e "B", ou "B" e "C" no sentido vestibulolingual, além dos contatos de "parada" e "equilíbrio" no sentido mesiodistal. Os dentes anteriores passam a funcionar em movimentos mandibulares, desocluindo de imediato os dentes posteriores, o que é denominado de guia anterior, visando equilíbrio muscular e proteção do sistema estomatognático. O desgaste seletivo não deve ser utilizado como substituto da movimentação ortodôntica. Objetivo: apresentar os princípios relacionados ao ajuste oclusal em Ortodontia.
\end{abstract}

Palavras-chave: Ajuste oclusal. Ortodontia. Desgaste seletivo. Equilíbrio oclusal. Estabilidade dentária.

\section{INTRODUÇÃO}

O conceito da multidisciplinaridade no exercício da Odontologia é considerado fundamental para o alcance da excelência nos tratamentos. Neste contexto, cada uma das especialidades precisou rever seu campo de ação, encontrando facilidades e dificuldades durante este processo de evolução.
Podemos contabilizar para a Ortodontia ganhos importantes, facilitadores do tratamento, como a ancoragem absoluta do implante, melhora da forma e volume dentário através da Odontologia Cosmética, redução dos riscos periodontais, dentre outros incontáveis benefícios ao paciente. Por outro lado, tivemos que sair do casulo de nossa es-

\footnotetext{
* Mestre em Ortodontia pela UFRJ. Doutor em Ortodontia pela UNESP-Araraquara. Professor de Ortodontia da UFES. Diplomado pelo Board Brasileiro de Ortodontia.

** Especialista em Ortodontia pela UFF.
} 
pecialidade, muito ligada ao raciocínio mecânico, para aumentar nosso espectro de conhecimento e atuação, incorporando conceitos e práticas atuais.

O conhecimento da oclusão dentária saiu da exclusividade da Prótese, com escolas mais ou menos ortodoxas ${ }^{18,35}$, para invadir discussões sobre patologia, função e estabilidade em todas as áreas da Odontologia. Embora com alguns paradigmas em aberto, protocolos podem ser definidos para que possamos ter uma linguagem comum a todas as especialidades, e para que parâmetros similares de qualidade sejam alcançados.

Para o ortodontista, o domínio dos conceitos de oclusão normal e das seqüelas do trauma oclusal vai muito além da multidisciplinaridade. De fato, estaremos discutindo neste tópico especial a base da Ortodontia, aquilo que deveria ser considerado em cada paciente atendido, todos os dias no consultório e, principalmente, discutido nas salas de aula e clínicas de pós-graduação. Casos bem finalizados geram maior satisfação de pacientes e profissionais, e diminuem recidivas ${ }^{6,10}$.

O objetivo deste artigo é definir maneiras de se incorporar a análise da oclusão dentária na rotina do ortodontista, aumentando a qualidade dos resultados. O equilíbrio oclusal é considerado fator de estabilização dentária e parte importante na busca pela excelência na Ortodontia, estando associado à diminuição do tempo de tratamento, ao contrário do que parece ser o senso comum. Serão abordadas regras, objetivos e procedimentos para o ajuste oclusal por desgaste, realizado antes, durante e após o tratamento ortodôntico.

\section{EQUILÍBRIO OCLUSAL E A ESTABILIZAÇÃO DENTÁRIA}

O Glossário de Termos Protéticos da Academia Americana de Prótese de 1999 define equilíbrio oclusal como "a modificação dos formatos oclusais dos dentes com a intenção de igualar as tensões oclusais, produzindo contatos oclusais simultâneos ou harmonizando as relações intercuspídicas", uma visão que excluía a Ortodontia como recurso para o alcance da melhor oclusão.

Atualmente, define-se equilíbrio oclusal como a obtenção de contatos oclusais em que prevaleçam as resultantes de forças no sentido axial ${ }^{26}$. As resultantes horizontais da força de oclusão são indesejáveis, pois geram tendência ao movimento, comprometendo a estabilização dentária e mandibular, devendo então haver distribuição de contatos pelos planos inclinados dos dentes, em direções opostas, de forma que se anulem mutuamente. Da mesma forma, há necessidade de que se distribua a força da oclusão sobre todos os dentes posteriores para que haja contatos bilaterais simultâneos e eqüipotentes, evitando a sobrecarga em determinadas regiões ou desvios mandibulares que gerem esforços sobre poucos dentes ${ }^{28}$ (Fig. 1, 2). O periodonto receberia, assim, estímulo fisiológico, produzindo fibras colágenas e mantendo a espessura das trabéculas ósseas no osso alveolar.

Alguns autores, especialmente os gnatologis$\operatorname{tas}^{18,35}$, atribuem a responsabilidade pela recidiva exclusivamente a tratamentos ortodônticos sem distribuição de contatos oclusais adequados ou ausência de estabilização mandibular, que geram forças horizontais residuais, que por sua vez movimentam dentes em busca da estabilidade. Embora esta lógica seja verdadeira em muitos casos, uma constatação contrapõe esta rigidez conceitual: algumas vezes, recidivas acontecem em oclusões com contatos bem estabelecidos e sem desvios de posição mandibular importantes, quando as posições de Relação Cêntrica (RC) e Máxima Intercuspidação Habitual (MIH) estão praticamente coincidentes.

É importante considerar que a estabilidade dentária é constituída por um tripé, onde além do equilíbrio oclusal, há necessidade de dois outros fatores estarem presentes. Deve haver uma base óssea hígida que possa contrapor pequenos gradientes de pressão muscular, considerados fisiológicos como, por exemplo, a pressão da língua que, em geral, está levemente mais elevada que a da musculatura orbicular e jugal. A terceira parte que 

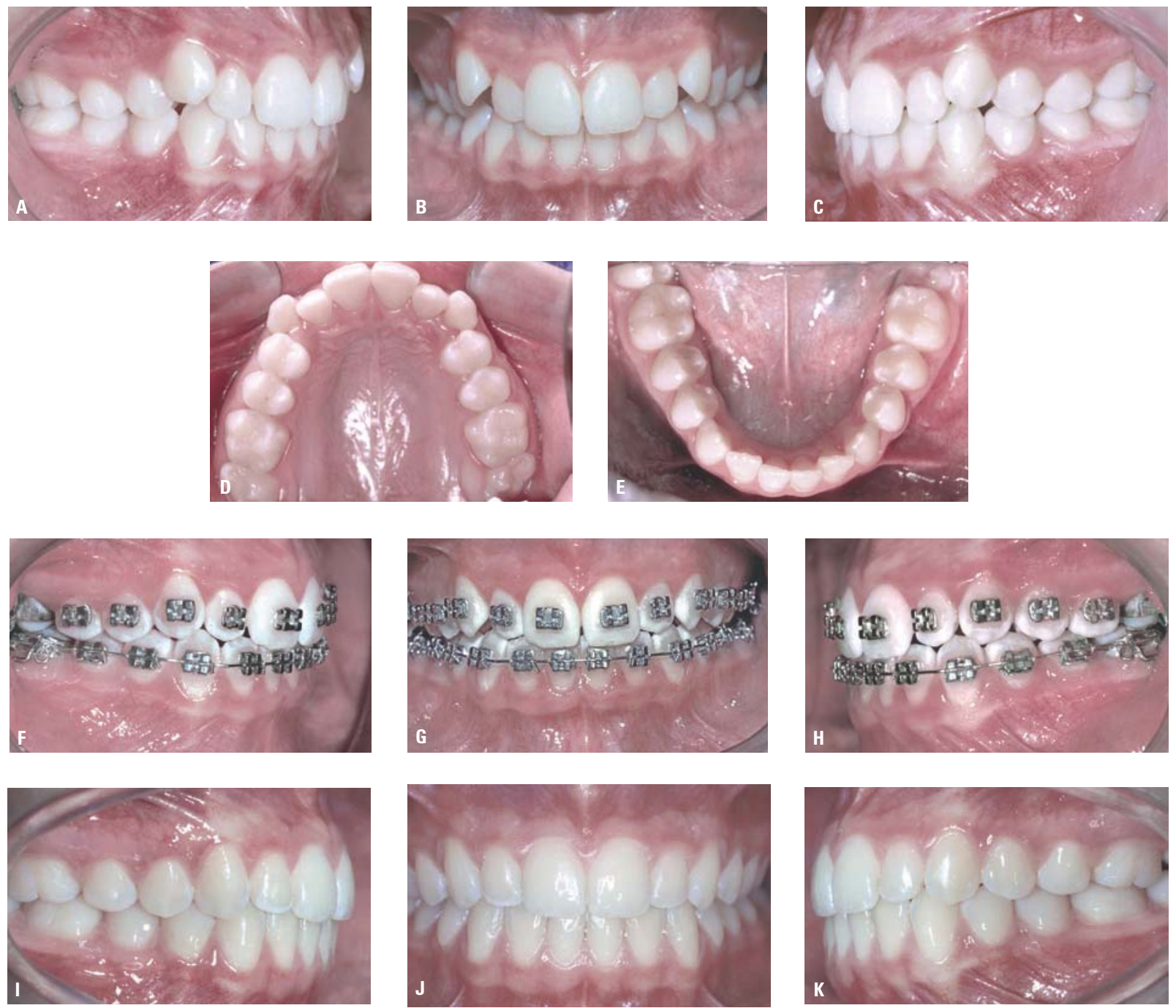

FIGURA 1 - Caso 1: apinhamento dentário sem extrações. A-E) Caso inicial: apinhamento dentário acentuado no arco superior. F, G, H) Tratamento com aparelho extrabucal para ganho de espaço, sucedido de aparelho fixo. I, J, K) Resultado final, com bom aspecto morfológico da oclusão dentária.

sustenta a estabilização dentária é a musculatu$\mathrm{ra}^{13}$, pois alterações de pressão por função muscular atípica geram forças em intensidade e duração que vão além daquelas geradas pela oclusão dentária excelente e pela higidez óssea. Podemos citar como exemplo: hipertonia do músculo mentalis, causando apinhamento dentário inferior; postura lingual constantemente projetada, promovendo abertura da mordida; e respiração bucal, levando ao estreitamento e projeção do arco superior, mesmo diante dos melhores contatos oclusais obtidos pelo ortodontista.
Portanto, devemos buscar o equilíbrio oclusal como um dos fatores para determinação da estabilidade dentária, que pode ser alcançada com conhecimento e controle da mecânica ortodôntica. Movimentos dentários específicos devem ser orientados pela checagem oclusal, havendo necessidade de se conhecer os contatos oclusais e a resultante de forças sobre os dentes, para então definir meios de modificá-los ${ }^{17,18}$.

Para se entender melhor o equilíbrio oclusal, descreveremos os tipos de contatos entre os planos inclinados das cúspides dos dentes posteriores, 

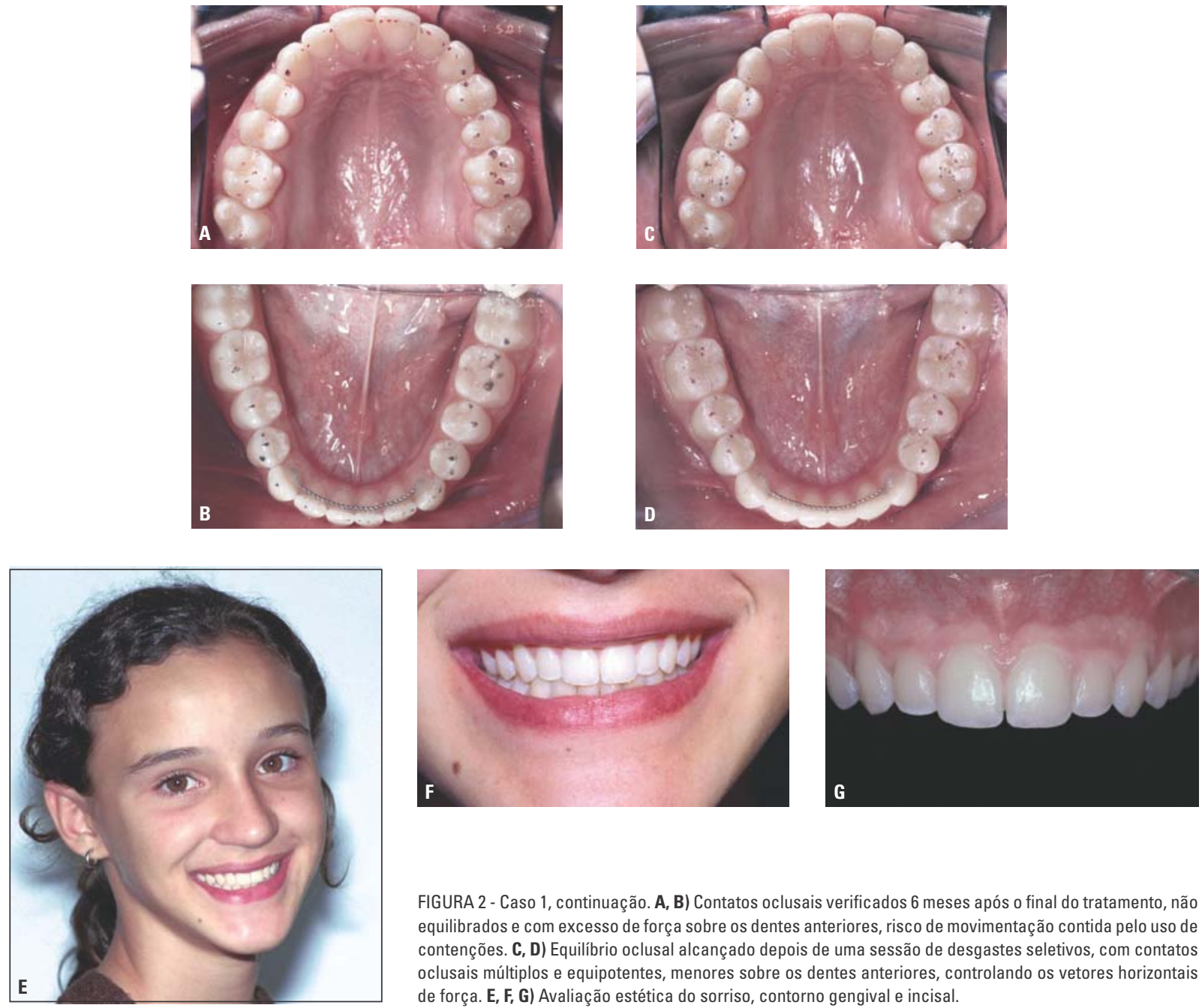

FIGURA 2 - Caso 1, continuação. A, B) Contatos oclusais verificados 6 meses após o final do tratamento, não equilibrados e com excesso de força sobre os dentes anteriores, risco de movimentação contida pelo uso de contenções. C, D) Equilíbrio oclusal alcançado depois de uma sessão de desgastes seletivos, com contatos oclusais múltiplos e equipotentes, menores sobre os dentes anteriores, controlando os vetores horizontais de força. E, F, G) Avaliação estética do sorriso, contorno gengival e incisal.

e a decomposição dos vetores de forças que agem sobre os dentes ${ }^{19,20}$ (Fig. 3-9).

\section{Sentido vestibulolingual}

1) Contato "A": estabelecido entre a vertente triturante da cúspide de não-contenção do dente superior (vestibular) com a vertente lisa da cúspide de contenção do dente inferior (vestibular). Neste caso, gera-se uma força diagonal que pode ser decomposta em vetores que vão agir sobre os dentes nos planos vertical e horizontal. Considera-se as resultantes verticais como forças axiais, dirigidas e dissipadas pelo periodonto de forma benéfica, normalmente como estímulo, previamente descri- to. Por outro lado, a resultante horizontal sobre o dente superior tende a movimentá-lo para vestibular - o que, além do desalinhamento dentário, levaria à diminuição da espessura do peridonto, gerando maior risco de recessão periodontal neste dente. Segundo Zachrisson ${ }^{42}$, o aparecimento da recessão periodontal em dentes que se movimentam para vestibular pode não ser imediato, e sim tardio, quando o paciente está fora do controle do ortodontista. No caso dos molares superiores, a possibilidade de exposição de furca pode também comprometer a longevidade do dente. Quanto ao dente inferior, esta resultante horizontal não antagonizada levaria à sua movimentação para lingual, 

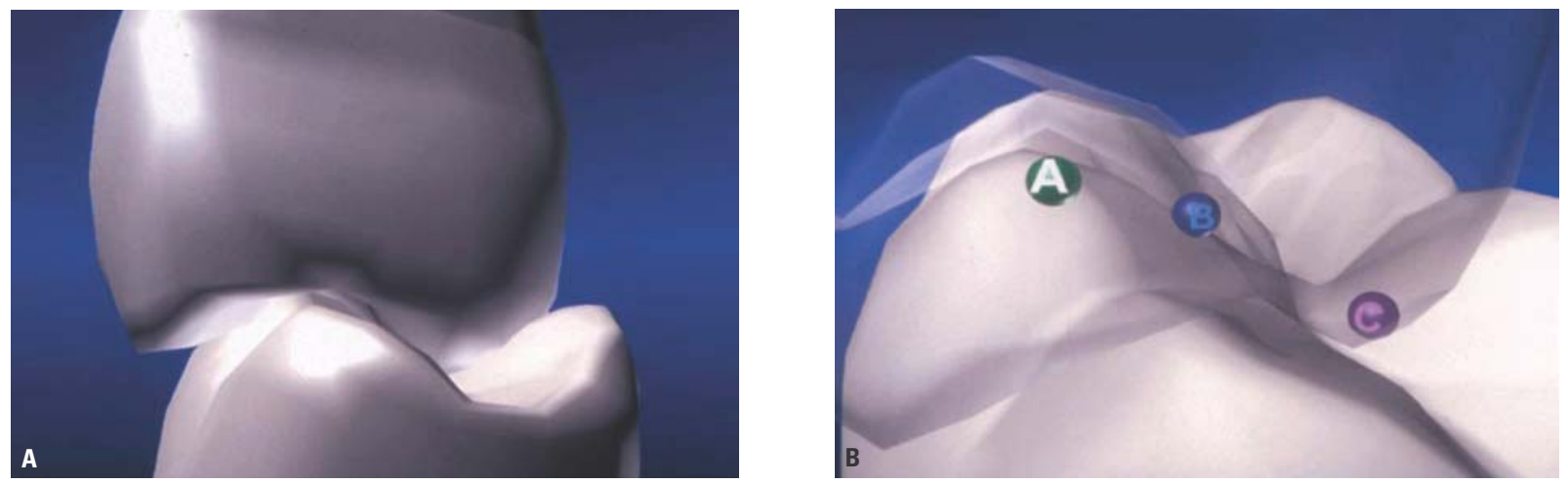

FIGURA 3 - Contatos oclusais no sentido vestibulolingual. A) Visualização da oclusão dentária no sentido vestibulolingual quando os dentes estão bem posicionados em suas bases ósseas. As cúspides de contenção cêntrica, palatina superior e vestibular inferior, ocluindo no sulco central do dente antagonista. B) Contatos "A", "B” e "C", nos planos inclinados das cúspides próximos às pontas das cúspides de contenção (Imagens cedidas por Dr. Paulo Isaias Seraidarian).

comprometendo, além do ponto de contato, o perímetro do arco, gerando apinhamento ou projetando dentes inferiores (Fig. 4).

2) Contato "B": estabelecido entre a vertente triturante da cúspide de contenção do dente superior (lingual) com a vertente triturante da cúspide de contenção do dente inferior (vestibular). Neste caso, uma força diagonal é sempre gerada, e sua decomposição em vetores leva a resultantes verticais (axiais) desejáveis e resultantes horizontais indesejáveis, quando este for o único contato oclusal presente. Quanto ao dente superior, a força tende a movimentá-lo para lingual, comprometendo a largura do arco, causando atresia e projeção dos dentes superiores. No arco inferior pode levar ao desvio mandibular, gerando mordida cruzada funcional ou contatos horizontais pesados do outro lado do arco (Fig. 5).

3) Contato " $C$ ": estabelecido entre a vertente lisa da cúspide de contenção do dente superior (lingual) com a vertente triturante da cúspide de nãocontenção do dente inferior (lingual). Neste caso, como mostra a figura 5 , a prevalência deste contato resultaria em vetores de força e conseqüências similares àquelas descritas para o contato "A" (Fig. 6).

Compreendendo os princípios da Física para se alcançar o equilíbrio oclusal e conseqüente estabilização dentária, é necessário que haja entre den- tes antagonistas o estabelecimento de uma das três situações: presença de contatos "A" e "B", presença de contatos "B" e "C" ou presença de contatos " $\mathrm{A}$ ", "B" e "C", sendo o contato "B" maior neste último caso. Avaliados pelo escore PAR, casos finalizados com alta qualidade de oclusão são mais estáveis e apresentam menos recidivas quando comparados a casos mal finalizados ${ }^{10}$. Da mesma forma, Burstone $^{6}$ correlaciona a estabilidade de resultados à prevalência de vetores axiais através do longo eixo dos dentes e vetores horizontais equilibrados.

\section{Sentido mesiodistal}

1) Contato de "parada" ("stopper"): estabelecido entre a aresta distal da cúspide do dente superior com a atresta mesial da cúspide inferior ${ }^{19,20}$. Por também serem planos inclinados, gera-se uma força diagonal que pode ser decomposta em vetores que vão agir sobre os dentes no plano vertical e horizontal. Desconsiderando-se as forças axiais, dissipadas pelo periodonto, restam as resultantes horizontais. Quanto ao dente superior, a força tende a movimentá-lo para mesial, produzindo como efeito indesejável o aumento do overjet pela projeção dos dentes anteriores. No caso do arco inferior, a resultante horizontal não-antagonizada teria como principal risco a possibilidade de empurrar a mandíbula para distal, podendo comprimir a re- 

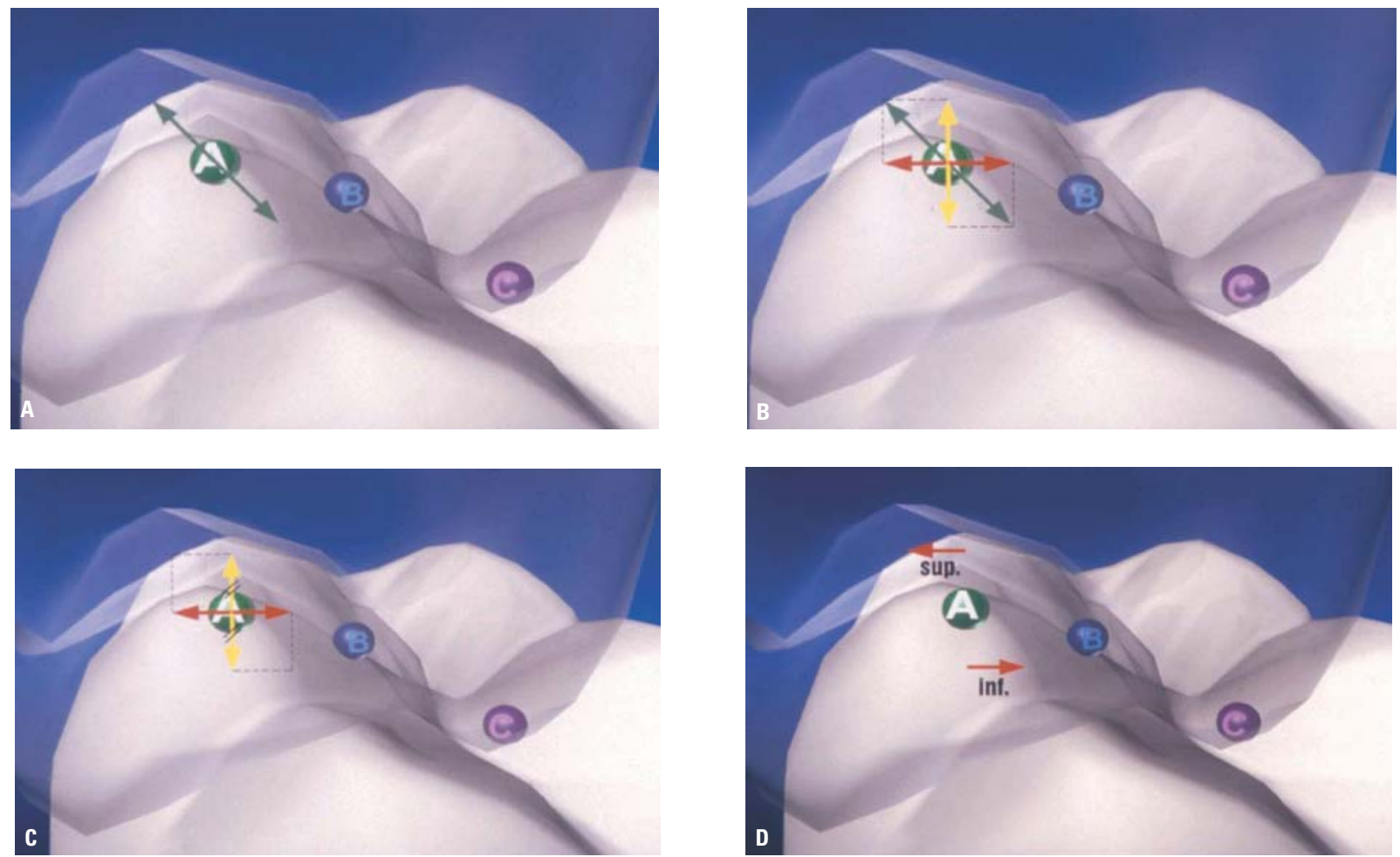

FIGURA 4 - Contato "A", direção da força oclusal e vetores de força. A) Direção de força pelo contato entre a vertente triturante da cúspide de não-contenção superior com a vertente lisa da cúspide de contenção inferior; B) decomposição da força de oclusão em vetores axiais (amarelo) e horizontais (vermelho); C, D) vetores axiais são dissipados pelo periodonto, restando os vetores horizontais que levariam à movimentação vestibular do dente superior e lingual do inferior, ou desvio mandibular para 0 lado oposto (Imagens cedidas por Dr. Paulo Isaias Seraidarian).
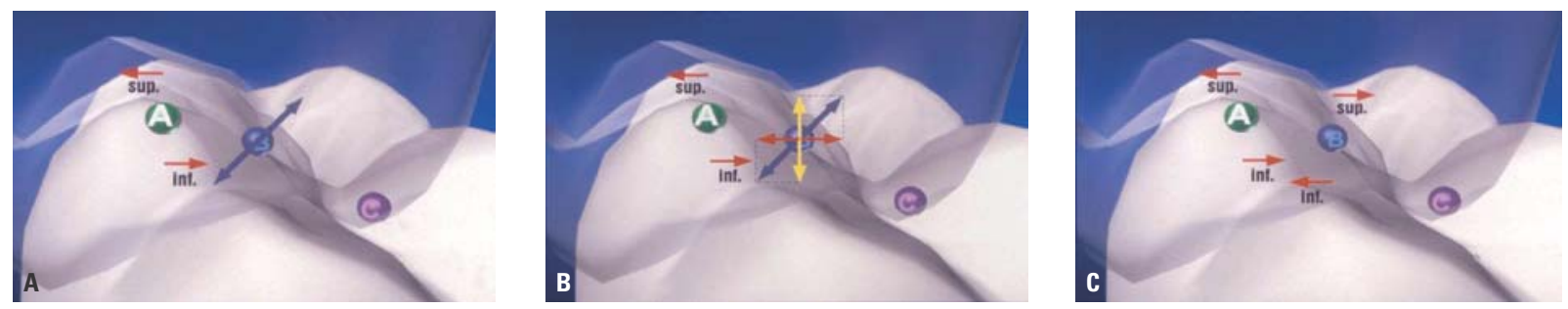

FIGURA 5 - Contato "B", direção da força oclusal e vetores de força: A) direção de força pelo contato entre a vertente triturante da cúspide de contenção superior com a vertente triturante da cúspide de contenção inferior; B) decomposição da força de oclusão em vetores axiais (amarelo) e horizontais (vermelho); C) vetores horizontais remanescentes que levariam à movimentação lingual do dente superior e vestibular do inferior, ou desvio mandibular para o mesmo lado. Note que os vetores remanescentes do contato "A" antagonizam os do contato "B" (Imagens cedidas por Dr. Paulo Isaias Seraidarian).
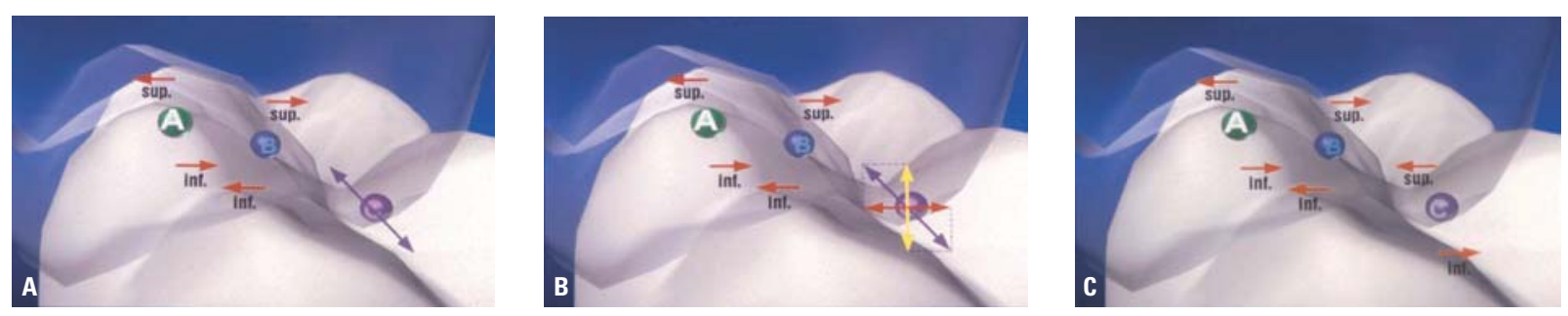

FIGURA 6 - Contato "C", direção da força oclusal e vetores de força: A) direção de força pelo contato entre a vertente lisa da cúspide de contenção superior com a vertente triturante da cúspide de não-contenção inferior; B) decomposição da força de oclusão em vetores axiais (amarelo) e horizontais (vermelho); C) vetores horizontais remanescentes que levariam à movimentação análoga à do contato " $\mathrm{A}$ ". Ocorre o equilíbrio quando a soma dos vetores dos contatos " $\mathrm{A}$ " e " $\mathrm{C}$ " é antagonizada pelo contato "B" (Imagens cedidas por Dr. Paulo Isaias Seraidarian). 


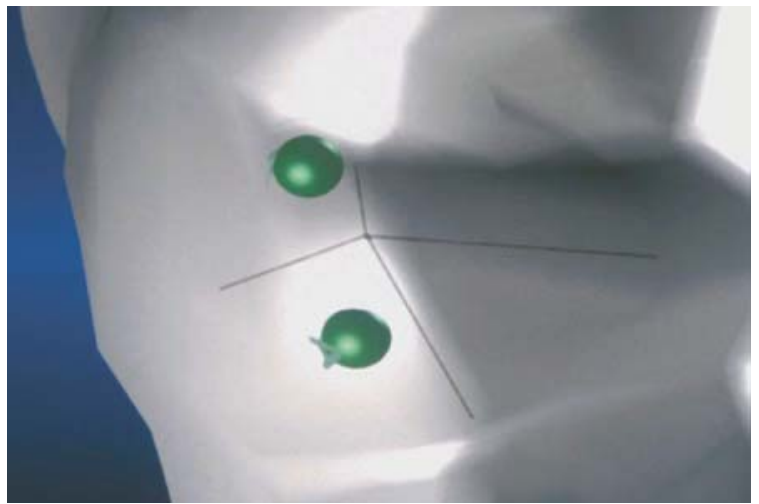

FIGURA 7 - Visualização da cúspide de dente posterior, considerada no sentido mesiodistal. Contatos de "parada" e "equilíbrio" nos planos inclinados mesial e distal das cúspides (Imagem cedida por Dr. Paulo Isaias Seraidarian).

gião posterior da articulação temporomandibular (ATM), altamente inervada e vascularizada. Embora a literatura não mostre evidência de degeneração articular em conseqüência da prevalência de contatos de "parada", poderia ser um fator adicional a parafunções, como o apertamento dentário, estabelecendo patologia articular (Fig. 7, 8);

2) Contato de "equilíbrio" ("equalizer"): estabelecido entre a aresta mesial da cúspide do dente superior com a aresta distal da cúspide inferior. A prevalência deste contato gera resultantes horizontais que tendem à movimentação para distal dos dentes superiores, abrindo os contatos interproximais. Entretanto, o maior problema da falta do contato de parada é o desvio da mandíbula para anterior, fugindo da interferência no fechamento. Se houver presença da barra lingual colada como contenção inferior, haverá estabelecimento de contatos fortes entre os dentes anteriores, cuja resultante é sempre horizontal. $\mathrm{Na}$ ausência da contenção superior, esta força causará protrusão dos dentes superiores, com abertura de diastemas e todo risco periodontal associado. Por outro lado a falta da contenção inferior ou hipertonia do músculo orbicular dos lábios promoverá apinhamento dentário inferior, como acontece quando há crescimento mandibular tardio (Fig. 9).

Buscando o equilíbrio oclusal e a estabilização dentária no sentido mesiodistal, indica-se finalizar o tratamento ortodôntico com contatos de parada e de equilíbrio estabelecido na maioria dos dentes posteriores.

Em relação aos dentes anteriores, define-se como relação adequada, quando o contato em $\mathrm{MIH}$ não gera forças horizontais importantes. Isto pode ser avaliado clinicamente de duas maneiras: (a) pela checagem da magnitude dos contatos, verificada com papel de marcação (Accufilm II ${ }^{\circledR}$ ) e depois conferindo com papel celofane, que não deve rasgar quando puxado com os dentes em oclusão; e (b) manipulando o paciente em RC e pedindo para ele morder até MIH. Enquanto o paciente executa a manobra, a polpa digital dos dedos indicador e médio tocará a superfície vestibular dos incisivos, e vibração nestes dentes não deverá ser percebida. A presença desta vibração, descrita como Frêmito ou Fremitus, indica força horizontal excessiva com risco de movimentação dentária para vestibular conseqüente ao desvio entre $\mathrm{RC}$ e $\mathrm{MIH}^{40}$. Muitas das recessões periodontais em dentes anteriores, ocorridas após a Ortodontia, podem ser explicadas pela movimentação para vestibular destes dentes, conseqüente à ação de forças horizontais remanescentes do tratamento ortodôntico.

\section{DINÂMICA DA OCLUSÃO}

Ao se considerar as posições de RC e MIH, surgem duas questões: qual a melhor posição para o tratamento ortodôntico? Como encontrar a posição de RC?

A melhor posição para o tratamento ortodôntico é aquela que pode ser reproduzida a cada consulta do paciente, e a única posição reproduzível é a $\mathrm{RC}^{4,32,33}$. Mais do que isto, devemos nos preocupar com parâmetros desde o início do tratamento, para não termos o dissabor de iniciarmos um caso de simples apinhamento dentário em má oclusão Classe I de Angle e nos depararmos, após os primeiros arcos de nivelamento, com uma Classe II divisão 1 com indicação cirúrgica, 

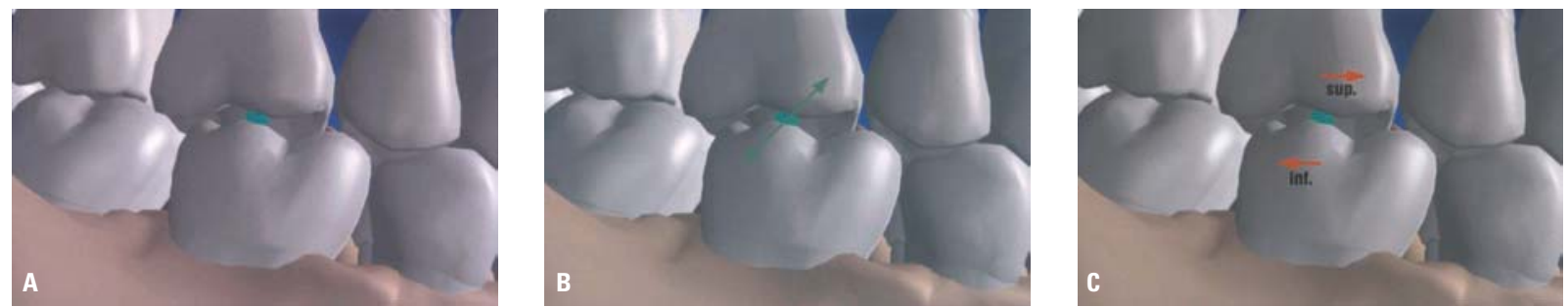

FIGURA 8 - Contato de "parada", direção da força oclusal e vetores de força: A) contato entre a aresta distal da cúspide superior com a aresta mesial da cúspide inferior; B) direção da força de oclusão resultante dos planos inclinados; C) vetores horizontais remanescentes que levariam à movimentação para mesial dos dentes superiores, aumentando o overjet, e para distal nos dentes inferiores, abrindo espaços ou comprimindo o côndilo contra a região posterior da cavidade articular (Imagens cedidas por Dr. Paulo Isaias Seraidarian).
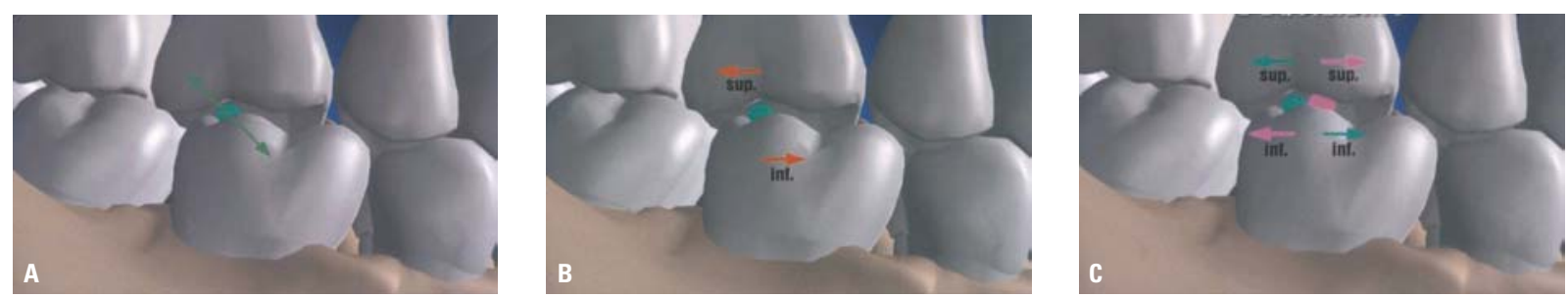

FIGURA 9 - Contato de "equilíbrio", direção da força oclusal e vetores de força: A) contato entre a aresta mesial da cúspide superior com a aresta distal da cúspide inferior com a direção da força de oclusão resultante; B) vetores horizontais remanescentes que levariam à movimentação para distal dos dentes superiores, abrindo contatos, e para mesial nos dentes inferiores, causando apinhamento inferior, ou deslocando a mandíbula para anterior, gerando Frêmito e abrindo diastemas pela vestibularização dos dentes superiores, com risco de recessão periodontal. C) Ocorre o equilíbrio quando a soma dos vetores dos contatos de "parada" (setas rosas) é antagonizada pelo soma dos vetores dos contatos de "equilíbrio" (setas verdes) (Imagens cedidas por Dr. Paulo Isaias Seraidarian).

que precisaria ser justificada ao paciente como erro de diagnóstico ${ }^{36}$. Da mesma forma, podemos evitar o constrangimento de tratamentos intermináveis, pelo simples fato de a cada vinda do paciente uma nova posição mandibular ser encontrada, gerando ativações para movimentações dentárias em direções opostas às realizadas na consulta anterior.

Portanto, precisamos de parâmetros desde a consulta inicial e, a partir deste momento, a manipulação em RC é imprescindível durante todo o tratamento. Sem ser incoerente, considera-se completamente aceitável que haja, ao final do tratamento ortodôntico, uma pequena diferença de RC para $\mathrm{MIH}$ de até $3 \mathrm{~mm}^{38}$, com desvio anterior da mandíbula, desde que não gere forças horizontais excessivas sobre os dentes anteriores. Alguns autores ${ }^{38}$ consideram a diferença de $1,2 \mathrm{~mm}$ como compativel com a normalidade articular. Por outro lado, não são aceitáveis os desvios laterais da mandíbula que gerem forças horizontais imedia- tas e mais potentes sobre os dentes posteriores, nem adaptações musculares e articulares mais complexas.

A questão referente à posição condilar para obtenção da RC parece fácil de ser respondida quando se avalia cortes anatômicos da ATM e constatase que não existe muito espaço para ser ocupado pelo côndilo que, na normalidade, está situado em uma posição mais anterior e superior ${ }^{8,28}$ dentro da cavidade articular, guiado pelo tônus muscular. A manipulação, tanto bilateral quanto guiada pelo mento ${ }^{8}$, busca esta posição descrita, não devendo o operador usar pressão excessiva. Encontrando resistência ao procedimento, pode-se lançar mão de técnicas de relaxamento ou adiá-lo. O uso de placa oclusal por três a seis meses está indicado antes do início do tratamento ortodôntico em casos de desordem temporomandibular presente ou quando há dificuldade de manipulação do paciente para a obtenção da RC.

O alcance da normalidade oclusal em movi- 
mentos mandibulares é definido pelas características de anatomia e posição dos dentes. Ao finalizar o tratamento ortodôntico deve haver uma sobremordida adequada, normalmente entre 2 e $3 \mathrm{~mm}$.
Os contatos nos dentes anteriores devem ser mais leves em relação aos contatos entre dentes posteriores, no entanto, precisam ser efetivos para que haja imediata desoclusão destes dentes quando do
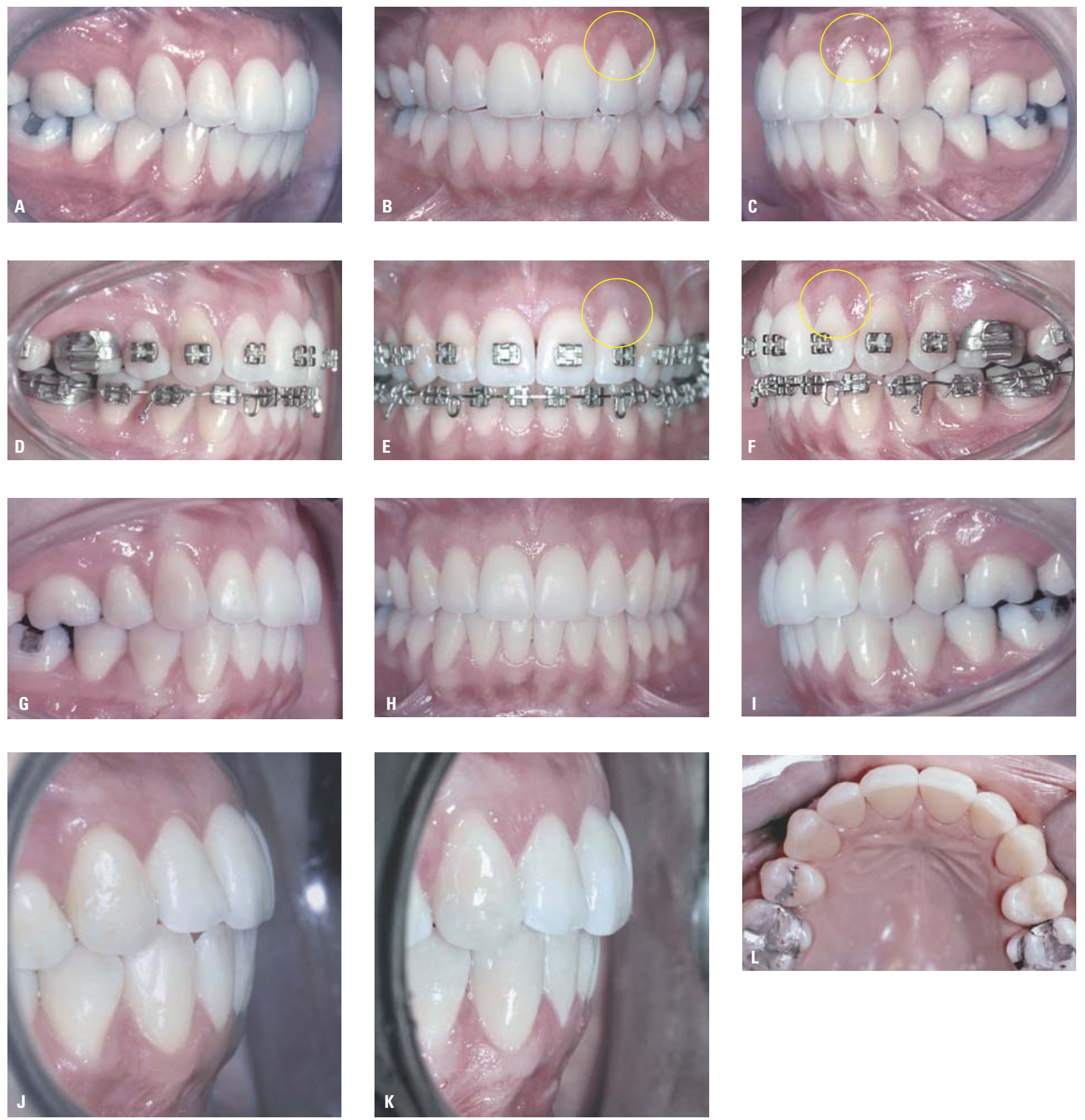

FIGURA 10 - Caso 2: paciente encaminhada pelo dentista clínico para retratamento, por apresentar falta de equilíbrio oclusal. A, B, C) Caso inicial, onde nota-se que foi tratado com exodontia de primeiros pré-molares e apresenta boa intercuspidação, mas sem o equilíbrio oclusal. A recessão periodontal no incisivo lateral superior esquerdo deve-se à movimentação para vestibular provocada pelo contato forte deste dente com o canino inferior. D, E, F) Caso em retratamento. Através de desgastes interproximais nos dentes anteriores obteve-se espaço para a retração dos incisivos inferiores, eliminando-se o trauma oclusal. G, H, I) 0clusão obtida ao final de 12 meses de tratamento, aspecto de saúde periodontal. $\mathbf{J}, \mathbf{K}, \mathbf{L}$ ) Comparação do overjet antes e depois do retratamento, onde a guia anterior passou a ser potencialmente efetiva, sem trauma e com eminente contato quando do movimento. 

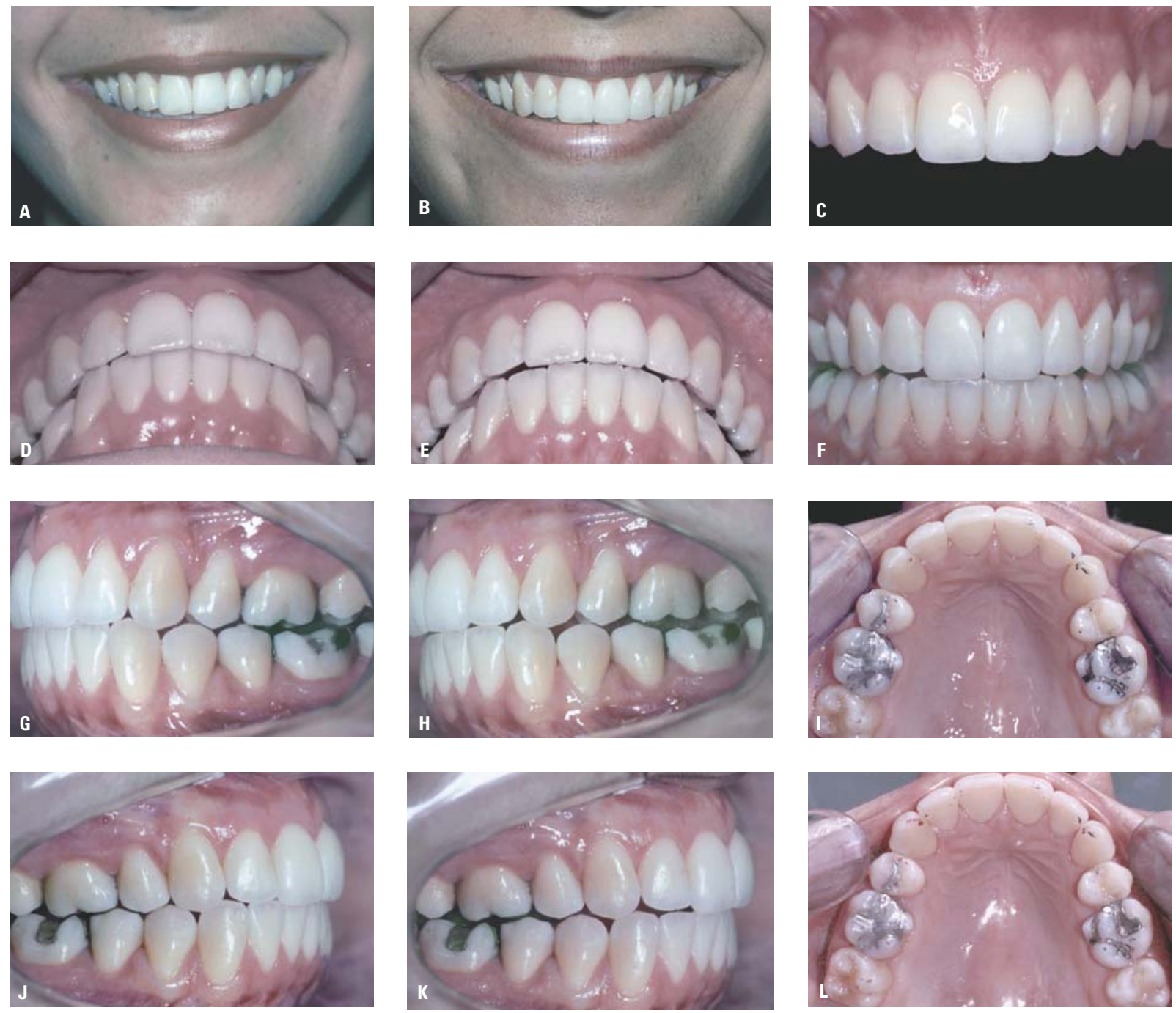

FIGURA 11 - Caso 2, continuação. A, B, C) Comparação do sorriso antes (A) e depois (B), onde foi alcançado melhor torque em caninos, assim como melhora no contorno gengival e na curva incisal. D, E, F) Avaliação do movimento de protrusiva desde o início com desoclusão imediata dos posteriores até o relacionamento de topo. G, H, I) Movimento mandibular em lateralidade esquerda, desoclusão pelo canino do início até o fim e a marcação da guia em caninos. J, K, L) Movimento de lateralidade direita, desoclusão pelo canino marcada em vermelho.

início do movimento mandibular. A falta de sobremordida adequada com contatos fortes gera vetores de forças horizontais indesejáveis, vestibularizando os dentes que "fogem" do trauma oclusal. Esta migração dentária para vestibular torna-se patológica, pois comprime o periodonto, gerando, conseqüentemente, a perda de osso cortical e a migração apical da inserção gengival. $\mathrm{O}$ efeito do movimento dentário para vestibular levando à recessão periodontal foi descrito por Zachrisson ${ }^{42}$ como um efeito iatrogênico que pode aparecer durante a Ortodontia ou se estabelecer de forma tardia após o tratamento finalizado (Fig. 10, 11).

Em movimentos mandibulares naturais deve-se evitar contatos dos planos inclinados dos dentes posteriores pela sua proximidade em relação aos músculos da mastigação, o que poderia gerar força horizontal excessiva sobre dentes e instabilidade articular. No caso de movimentos de lateralidade prefere-se a função de guia pelo canino ${ }^{1,7,23}$, pelas características de volume radicular, existência do pilar canino, maior prevalência e pela facilidade 
de obtenção durante o tratamento. $\mathrm{Na}$ ausência do canino, recomenda-se a função em $\operatorname{grupo}^{1,7,23}$, onde os contatos nas vertentes dos dentes superiores e inferiores do lado de trabalho são progressivamente menores, quando avaliados de mesial para distal. Se existe o estabelecimento natural da função em grupo, descrita anteriormente, não há porque transformá-la em guia canino, pois poderia comprometer a estética da curva do sorriso com caninos muito proeminentes. Em qualquer situação de função de lateralidade, guia canino ou grupo, não deve haver interferência dos dentes no lado de não-trabalho.

Durante a movimentação mandibular para anterior deve haver contatos dos quatro incisivos, podendo incluir os caninos. No final do movimento deve existir contato apenas dos centrais superiores com os quatro incisivos inferiores, considerando a menor força muscular nesta posição e a necessidade da prevalência dos incisivos centrais superiores na estética do sorriso. Portanto, durante toda a excursão mandibular protrusiva não poderão ocorrer interferências entre dentes posteriores $^{19,20,41}$. A importância de se estabelecer esta dinâmica da oclusão nos movimentos mandibulares é baseada na constatação de que os contatos em dentes anteriores são melhores compensados pela musculatura em ação do que em dentes posteriores, esta fisiologia mais adequada é definida como ação protetora dos dentes anteriores.

\section{PORQUE FAZER O AJUSTE OCLUSAL?}

Antes de qualquer abordagem, vale uma crítica ao título deste tópico especial, pois além de não existir apenas um tipo de ajuste oclusal, o próprio tratamento ortodôntico é um tipo de ajuste. Portanto, pode-se estabelecer o equilíbrio da oclusão por: 1) desgaste seletivo; 2) acréscimo através de restaurações ou próteses; 3 ) movimentação dentária e alteração ortopédica da Ortodontia combinada ou não à Cirurgia Ortognática; ou ainda 4) associação de dois ou três dos recursos descritos. Muito embora a palavra ajuste oclusal pressuponha desgastes, o mais amplo e mais conservador método é o realizado pela movimentação de dentes, distribuindo contatos oclusais, ao mesmo tempo que se posicionam as raízes dentárias para que possam receber as forças da oclusão da forma mais adequada.

Uma segunda verdade precisa ficar bem esclarecida: má oclusão não pressupõe patologia oclusal. Embora diante de uma desarmonia esquelética e/ou de um desalinhamento dentário, a maioria dos portadores de má oclusão não possui sinais de trauma oclusal, tais como: desgastes dentários, mobilidade, abfração, recessões periodontais nem desordens temporomandibulares. De fato, a movimentação ortodôntica é que gera trauma, e suas seqüelas são menores, quanto mais rápido e controlado for o tratamento. Sabemos que a parafunção, e não a má oclusão, é o principal fator causador de patologias oclusais ${ }^{28}$, e normalmente estas parafunções estão ligadas a fatores psicogênicos múltiplos.

Um paciente portador de má oclusão pode passar toda a sua vida sem ter patologias oclusais. No entanto, ao iniciar um tratamento ortodôntico ocorrem alterações do normal que, na maioria das vezes, não causam problemas mais graves, devido à estabilidade dentária decorrente de adaptações musculares e oclusais. Estas compensações presentes em um paciente portador de má oclusão possuem determinantes que desconhecemos ou não controlamos, e que podem ou não voltar a acontecer neste mesmo indivíduo em outra situação oclusal. Pelo fato de não haver evidência da capacidade do paciente e seus dentes se adaptarem a uma nova situação oclusal, que não a ideal, sem os adequados contatos para estabelecimento do equilíbrio oclusal, uma opção seria deixar por conta do acaso o paciente se adaptar àquela situação, como já se adaptou a má oclusão anterior. A outra seria lançar mão de todo o conhecimento e esforço para a finalização precisa dos casos, com controle do movimento dentário associado ao desgaste seletivo e, algumas vezes, procedimentos restauradores. 
Alguns autores ${ }^{12,15,16}$ demonstram não haver evidência de que o ajuste oclusal e o alcance do equilíbrio dentário sejam fatores determinantes para a estabilização dentária. De fato, os trabalhos que investigam o equilíbrio oclusal como o único, ou principal fator de estabilidade do tratamento ortodôntico, normalmente desconsideram os demais fatores, e escondem características individuais ou sazonais que serão consideradas a seguir.
Três aspectos da estabilidade pós-Ortodontia não podem ser negligenciados:

1) O equilíbrio oclusal não é o único fator que determina a estabilidade dentária, nem o mais importante. Fatores musculares, ligados a características genéticas e ambientas, parecem ter maior influência. Como a maioria dos problemas multifatoriais, a tentativa de detecção da causa das recidivas tende a não apresentar evidência, porque o
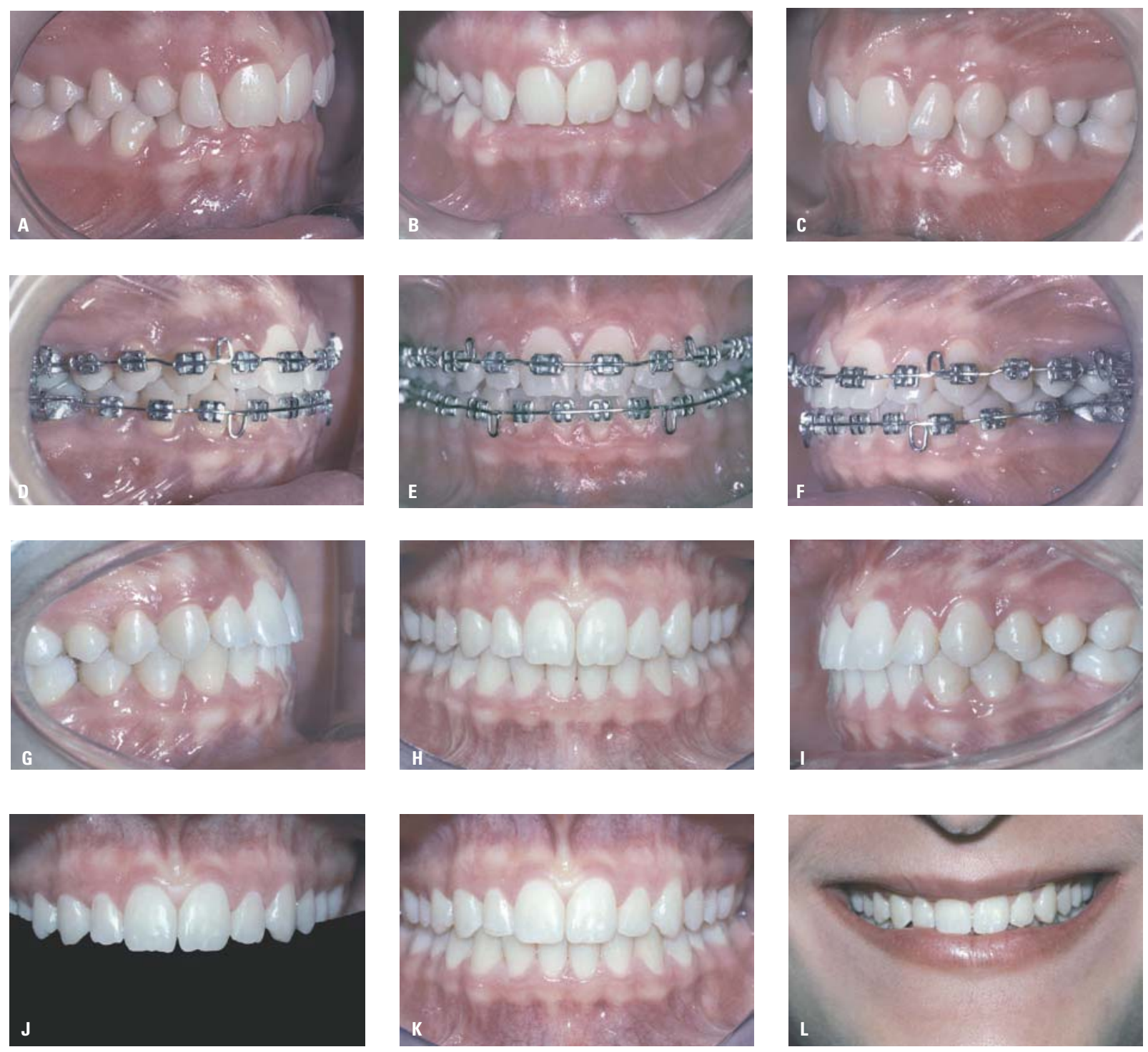

FIGURA 12 - Caso 3: canino superior direito incluso e sobremordida acentuada. A, B, C) Fotos iniciais, sobremordida acentuada e microdontia do incisivo lateral. D, E, F) Após abertura de espaço e tracionamento do canino, fechamento de espaços e finalização com arcos retangulares. G, H, I) Oclusão final obtida. J, K, L) Ajuste incisal para melhora estética, acompanhando a curva do sorriso. 
efeito é diluído ou mascarado por outros fatores, como é visto na maioria dos desenhos de pesquisa disponíveis na literatura ${ }^{3,29}$.

2) O mais importante - os contatos oclusais sem equilíbrio só podem gerar força e conseqüente movimento dentário quando considerada intensidade e duração. Uma força só gera movimento se exercida sobre um dente, em média, seis horas por $\mathrm{dia}^{31}$. Se forem somadas as horas que nossos dentes entram em contato, nas funções de mastigação e deglutição, dificilmente ultrapassarão 3 horas diárias, insuficientes para gerar movimento dentário.

3) Existe uma tendência natural ao aumento dos contatos oclusais, nos seis meses subseqüentes ao tratamento ortodôntico ${ }^{14,34}$, havendo uma melhora que pode compensar a menor qualidade na finalização dos tratamentos.
Todos estes fatores acima descritos explicam tanto a estabilidade encontrada na maioria dos casos tratados ortodonticamente sem requintes de finalização, assim como a dificuldade e carência de evidência científica, que possa definir o equilíbrio oclusal como fator determinante para a estabilidade dos tratamentos ortodônticos.

O que não é considerado nos estudos, e faz parte da realidade clínica, é a eventualidade do paciente vir a apresentar parafunções, como apertamento dentário, fazendo com que o tempo de contato oclusal aumente de maneira significativa, transformando forças de contato constantes em vetores de força cujo desequilíbrio passa a gerar movimentos dentários indesejáveis, já descritos anteriormente. Normalmente, o apertamento dentário está relacionado ao estresse, depressão ou angústia, mui-
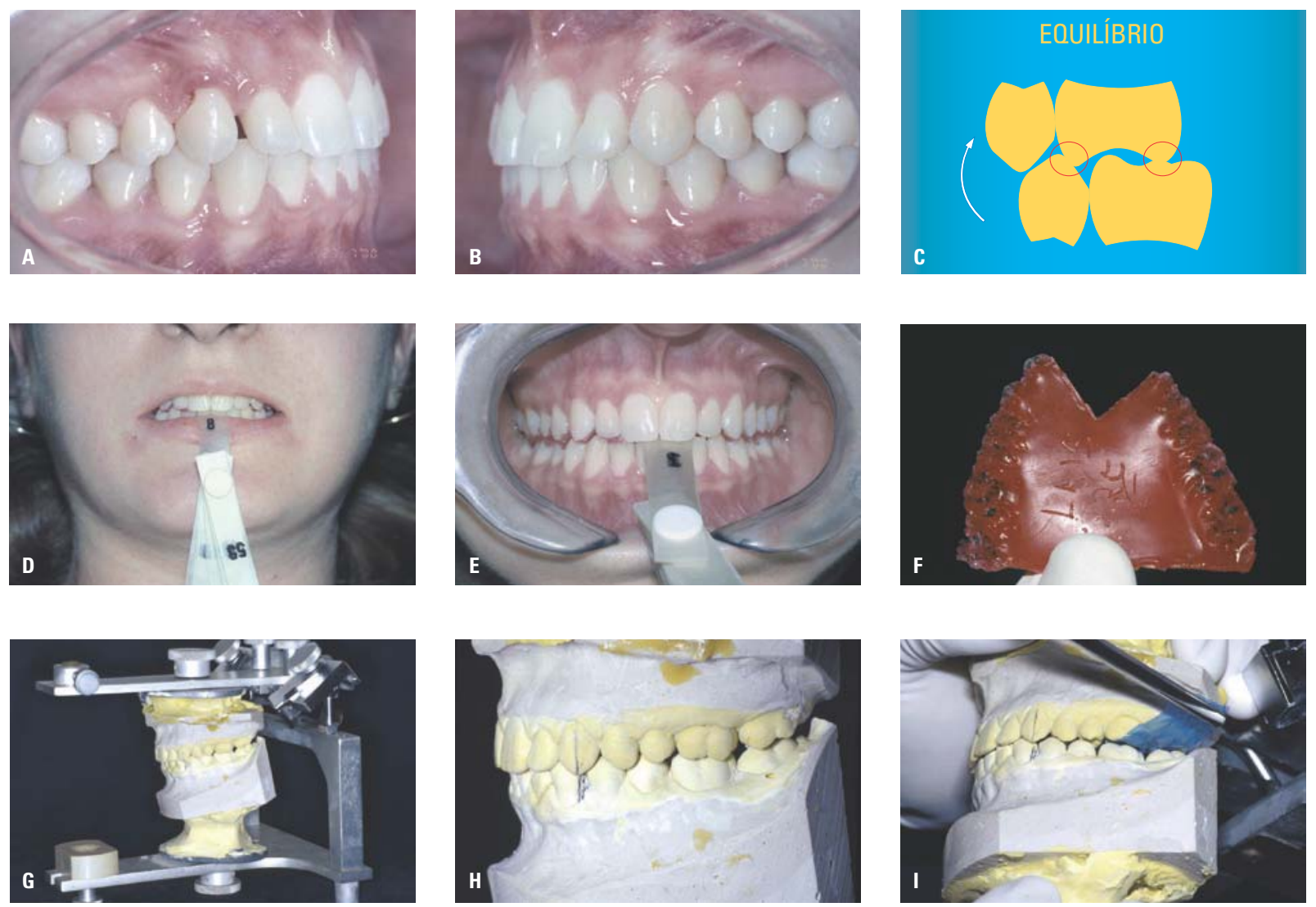

FIGURA 13 - Caso 3, continuação. A, B, C) Abertura de diastema por vestibularização de canino e incisivo lateral superior direito. D, E, F) Obtenção de registro de mordida em RC com uso das "Tiras de Long". G, H, I) Montagem em articulador, verificando desvio para anterior e para direita por contato de "Equilíbrio" no segundo molar do lado esquerdo. 

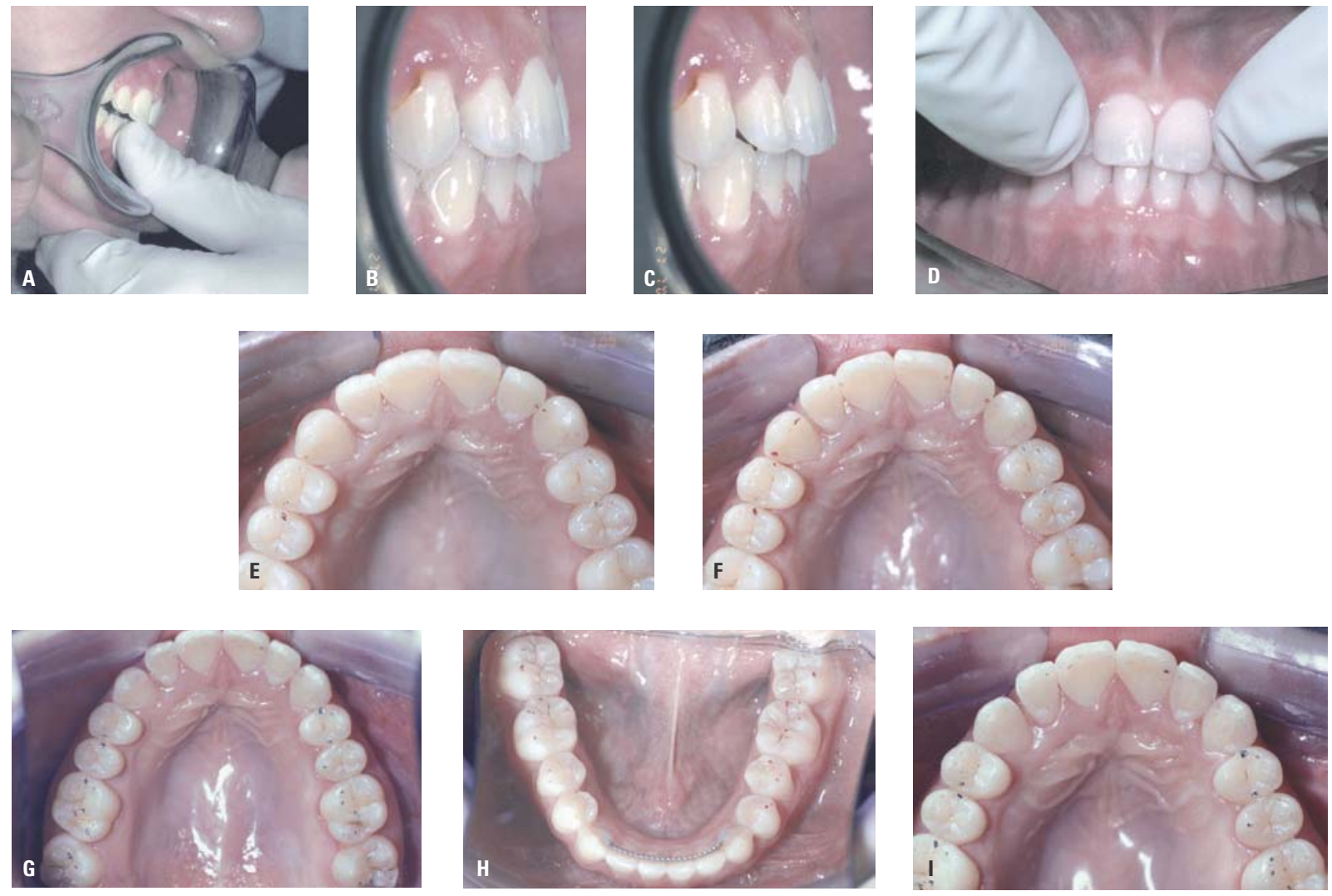

FIGURA 14 - Caso 3, continuação. A) Manipulação guiada do paciente para encontrar contato em RC. B, C, D) Verificação do desvio de RC para MIH de $1 \mathrm{~mm}$, mas que gerava vibração dos dentes superiores pela força horizontal resultante (Frêmito). E, F) Comparação dos contatos anteriores em RC (E) e MIH (F), que geram migração dentária para vestibular. G, H, I) Ajuste oclusal por desgaste, em RC, cujo limite é o contato suave dos dentes anteriores.

to comum na nossa sociedade. Estes episódios podem ser esporádicos, ou mesmo freqüentes, e podem pré-existir ou aparecer posteriormente ao tratamento ortodôntico. O exemplo desta seqüela pode ser visto onde há prevalência do contato de equilíbrio em detrimento do contato de parada, desviando a mandíbula para anterior durante a oclusão. A força horizontal, resultante do contato excessivo entre dentes anteriores em $\mathrm{MIH}$, causa abertura de diastemas anteriores e movimento vestibular destes dentes, com conseqüente recessão periodontal (Fig. 12-15).

O diagnóstico prévio de parafunções, como apertamento dentário e bruxismo, é mais fácil em indivíduos que apresentem-as com freqüência, especialmente se avaliados na fase aguda. Encontram-se facetas desgastadas, cúspides aplainadas, migrações dentárias com diastemas, mobilidade dentária, limitação da abertura bucal, estalos ou crepitações articulares, dores e edemas musculares. Normalmente não todas, mas algumas destas características estão presentes, dependendo do limiar de tolerância de cada indivíduo, já que algumas partes do sistema estomatognático podem ser mais resistentes ou suscetíveis à hiperfunção da musculatura mastigatória.

Como já incorporado ao nosso conhecimento por estudo clássico de McNamara, Selligman e Okesson ${ }^{21}$, sabemos que o papel da má oclusão como determinante de desordem temporomandibular (DTM) só tem correlação com cinco características oclusais: mordida aberta esquelética, overjet maior que 6 a $7 \mathrm{~mm}$, mordida cruzada unilateral, desvios de RC para $\mathrm{MIH}$ maior que $4 \mathrm{~mm}$, 

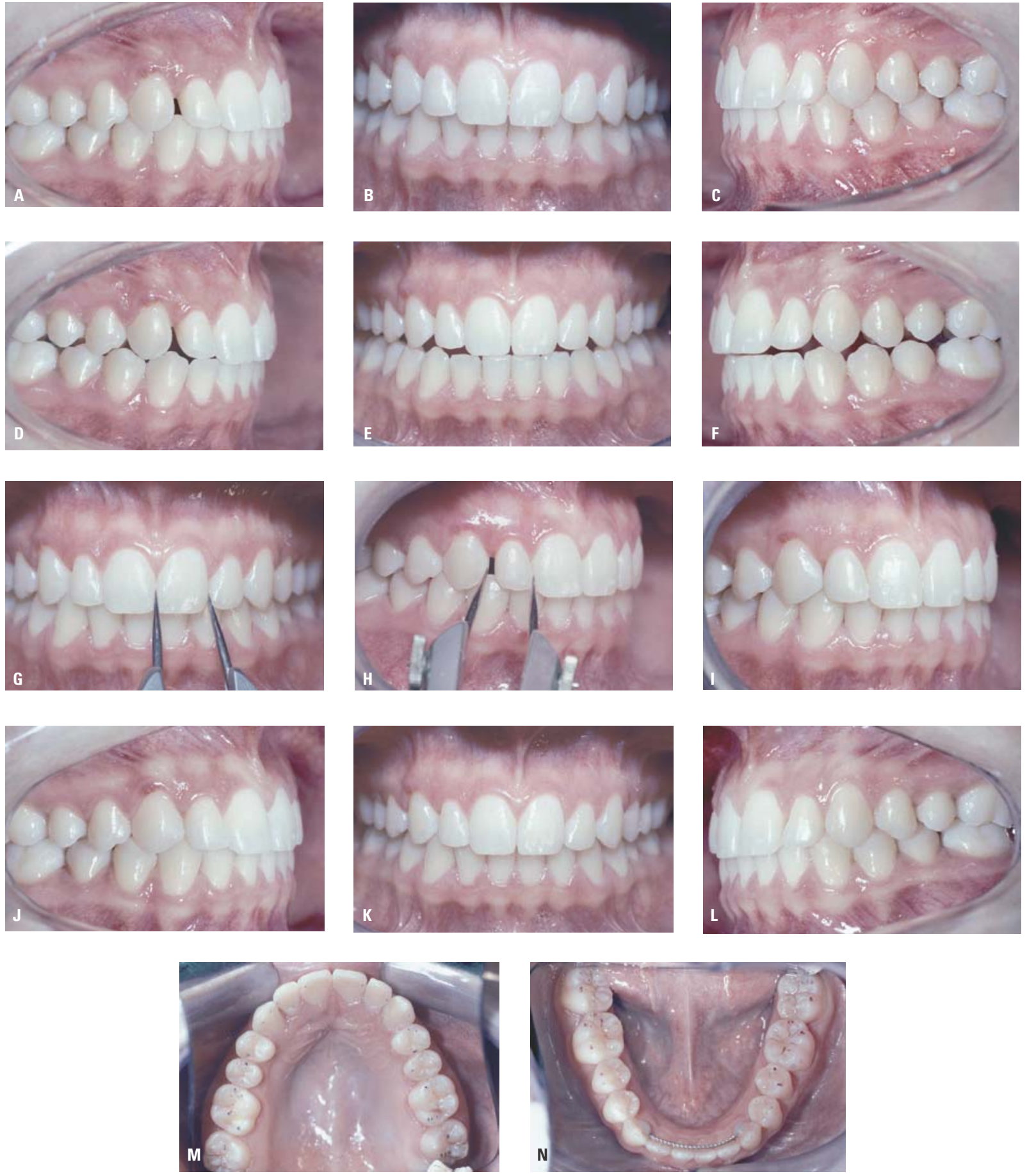

FIGURA 15 - Caso 3, continuação. A, B, C) Oclusão equilibrada após o ajuste em RC. D, E, F) Verificação das guias anteriores em movimentos mandibulares. G, H, I) Avaliação das proporções dentárias e opção por acréscimo em resina como melhor recurso para fechamento do diastema. J, K, L) Oclusão final com os procedimentos de desgaste e acréscimo, aliando estabilidade oclusal e estética. M, N) Contatos oclusais finais checados, RC coincidente com MIH. 
e perda de cinco ou mais dentes posteriores. Nestes casos a Ortodontia pode ser considerada como parte da terapêutica para as DTMs, com evidência científica $^{21}$. Da mesma forma, o tratamento ortodôntico não pode ser considerado causador de desordem temporomandibular nas suas diferentes técnicas e procedimentos ${ }^{37}$. Alguns achados clínicos comuns, como o aparecimento de estalos na ATM ou alterações musculares conseqüentes ao uso de elásticos intermaxilares, provavelmente estão ligados a parafunções da musculatura mastigatória desencadeados pela nova pressão ou pelo desconforto dos elásticos ou outros recursos terapêuticos.

O ajuste oclusal, por desgaste ou acréscimo, na finalização dos tratamentos ortodônticos, não pode ser considerado como prevenção à DTM e sim como complementar ao ajuste iniciado pela própria Ortodontia. Deve-se considerar no estabelecimento de uma nova oclusão: estética, função, estabilidade e ausência de patologias. Sendo assim, tornam-se necessários a busca pelo equilíbrio oclusal e o alcance da dinâmica da oclusão mais próxima do ideal.

\section{QUANDO OPTAR PELO AJUSTE OCLUSAL POR DESGASTE? \\ Antes da Ortodontia}

Ao revisar os conceitos da Ortodontia interceptora, verifica-se que o ajuste oclusal é indicado como técnica de tratamento para mordida cruzada funcional, de origem dentária ${ }^{17,25,30}$. Ou seja, antes do uso da mecânica ortodôntica, ou no lugar desta, o procedimento de desgaste seletivo, com uma nova distribuição dos contatos oclusais, busca a estabilização da nova posição mandibular, através do equilíbrio oclusal em Relação Cêntrica. Normalmente há um desvio de RC para MIH gerado por um contato "B" em RC, que movimenta a mandíbula para o lado oposto, causando mordida cruzada em MIH. Neste caso, ao se manipular o paciente em RC, deve-se verificar uma nova posição mandibular com coincidência das linhas médias. Portanto, a opção pelo ajuste oclusal só deve ser tomada se não houver atresia transversa do arco superior, que indicaria a disjunção palatina como terapia de eleição. $\mathrm{O}$ procedimento de ajuste visa o estabelecimento de contatos "B" dos dois lados para estabilização da posição da mandíbula, com MIH coincidente de RC, e conseqüente correção da mordida cruzada (Fig. 16).

\section{Durante a Ortodontia}

Talvez o maior benefício que o conhecimento da oclusão e a conseqüente aplicação do desgaste seletivo trazem para a Ortodontia é tornar factível uma movimentação dentária. Três problemas podem ser evitados com o procedimento de desgaste seletivo durante a movimentação ortodôntica: (1) seqüelas do trauma oclusal - mobilidade excessiva, dor prolongada e reabsorção radicular; (2) atraso para o término do tratamento - movimentos de vai-e-vem do dente e descontrole da mecânica; e (3) intercuspidação inadequada - falta de estabilidade na posição mandibular e risco de movimento dentário indesejável.

Quando se deseja movimentar dentes para melhor intercuspidação, normalmente lança-se mão de movimentos verticais, com degraus no arco ou recolagem de acessórios. Neste caso, é fundamental uma checagem oclusal com papel articular, para verificar se será possível o dente se movimentar em direção ao antagonista. Este simples procedimento possibilitará que interferências oclusais sejam eliminadas, tornando factível o movimento dentário. Simultaneamente, evitam-se seqüelas do trauma oclusal durante o tratamento, como mobilidade excessiva dos dentes e dor prolongada após a ativação dos aparelhos. Indivíduos com hipertonia muscular e pacientes tratados com elásticos verticais são os maiores beneficiados com o ajuste oclusal durante a Ortodontia, devido à redução das seqüelas iatrogênicas.

Outra situação indesejável acontece no tratamento de paciente portador de mordida aberta, normalmente com hipotonia muscular, quando a 

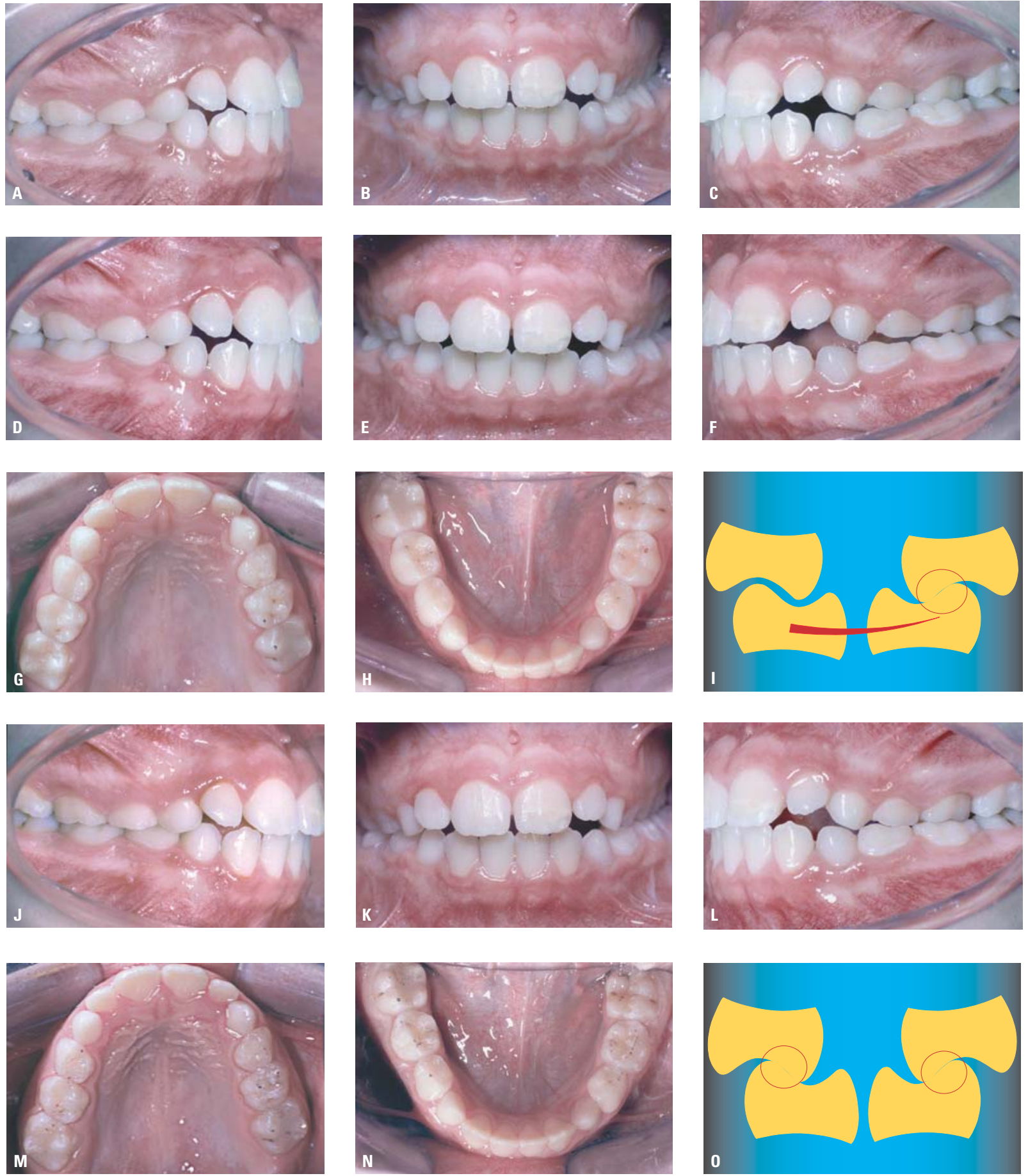

FIGURA 16 - Caso 4: mordida cruzada funcional de origem dentária. A, B, C) Caso inicial em MIH apresenta desvio da linha média e mordida cruzada unilateral esquerda. D, E, F) Manipulação em RC revela coincidência de linhas médias. G, H, I) Presença de contato "B" apenas de um lado dos arcos dentários, faz com que a mandíbula desvie para o mesmo lado, podendo gerar mordida cruzada funcional . J, K, L) Depois do desgaste seletivo a mandíbula se estabiliza em RC, centralizada na face, com linhas médias coincidentes. M, N, 0) Presença de contato "B" dos dois lados dos arcos dentários, fazendo com que a mandíbula estabilize no centro da face, impedindo a mordida cruzada funcional. (Imagens I e $\mathbf{0}$ cedidas por Dr. Paulo Isaias Seraidarian). 
tentativa de extrusão dentária para fechamento da mordida leva ao efeito oposto. Este efeito inverso da mecânica ortodôntica é explicado pelo "equilíbrio estático de forças" descrito por Mulligan ${ }^{26}$. Neste caso, após recolagem de braquetes ou incorporação de degraus no arco, estabelece-se a Geometria I ${ }^{5}$ (Fig. 17), em que há geração de forças em sentido contrário. Associados à extrusão dos dentes anteriores e intrusão dos posteriores ocorrem, simultaneamente, momentos nos braquetes no mesmo sentido, que se somam quanto mais degraus forem incorporados ${ }^{39}$. Neste caso, havendo um contato oclusal que impeça o movimento dentário de extrusão, o equilíbrio do sistema de forças pode produzir dois efeitos: a) intrusão dos dentes posteriores, estendendo a mordida aberta para trás; ou b) potencializando o momento gerado pelos binários de força, aumentando a mordida aberta anterior. O uso de elásticos verticais pesados pode impedir a abertura de mordida, mas gera
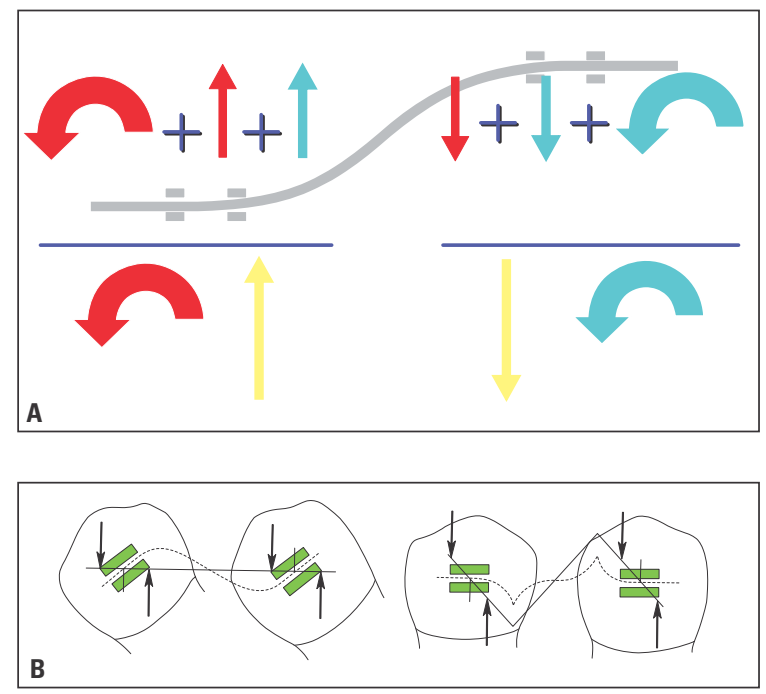

FIGURA 17 - Sistema de forças estatiscamente indeterminado: Geometria I. A) Quando o objetivo é de extrusão de dentes anteriores para fechar a mordida, e um sistema de degraus é incorporado, o equilíbrio estático do sistema acontece com forças em direções opostas, extruindo o dente anterior e intruindo o posterior, ao mesmo tempo em que dois binários são incorporados nos braquetes, no mesmo sentido. B) Não havendo o movimento dentário vertical, o efeito de vários binários iguais no mesmo sentido é somado e, junto com a inclinação dos dentes para frente, todo o arco dentário gira, abrindo ainda mais a mordida. enorme sobrecarga nos dentes em contato prematuro, provocando reabsorção radicular.

Sempre que há inconsistência na aplicação da mecânica, ocorre atraso no tratamento ortodôntico com agravamento do problema ou surgimento de novas dificuldades. Cumprir os prazos de tratamento traz credibilidade ao profissional. Muitos dos atrasos não estão relacionados à biologia e sim a problemas incorporados pelo próprio ortodontista durante o tratamento. Dois casos clínicos a seguir podem exemplificar como o alcance da melhor intercuspidação pode ser conseguido com procedimento simples de avaliação da oclusão e a eliminação de contato oclusal que impediria a movimentação, ou pior, causaria uma inversão no efeito da mecânica ortodôntica ${ }^{26,39}$. Para se contrapor o efeito de momentos iguais na mesma direção (Geometria I) ${ }^{5}$, que gera mordida aberta quando se deseja sobremordida com movimento dentário de extrusão de dentes anteriores, podese utilizar elásticos verticais anteriores, desde que sejam eliminados com desgaste seletivo contatos oclusais no segmento a ser extruído. Normalmente, estes contatos são de bordas incisais inferiores contra cristas marginais superiores, em dentes com anatomias atípicas ou alteradas por restaurações (Fig. 18-20).

De especial interesse para a finalização do tratamento ortodôntico é a intercuspidação dos dentes posteriores, um desafio que pode ser mais facilmente vencido a partir da análise oclusal. É importante considerar que pode haver uma discrepância oclusal, que representa a falta de compatibilidade anatômica para a perfeita intercuspidação entre dentes superiores e inferiores. Esta discrepância seria análoga àquela descrita por Bolton ${ }^{2}$ para o estabelecimento do melhor relacionamento mesiodistal dos dentes superiores com os inferiores, mas considerando agora a superfície oclusal no seu relacionamento vertical. Estamos falando de algo mais complexo, onde não há fórmulas matemáticas para se prever a existência ou a magnitude do problema. Por ou- 

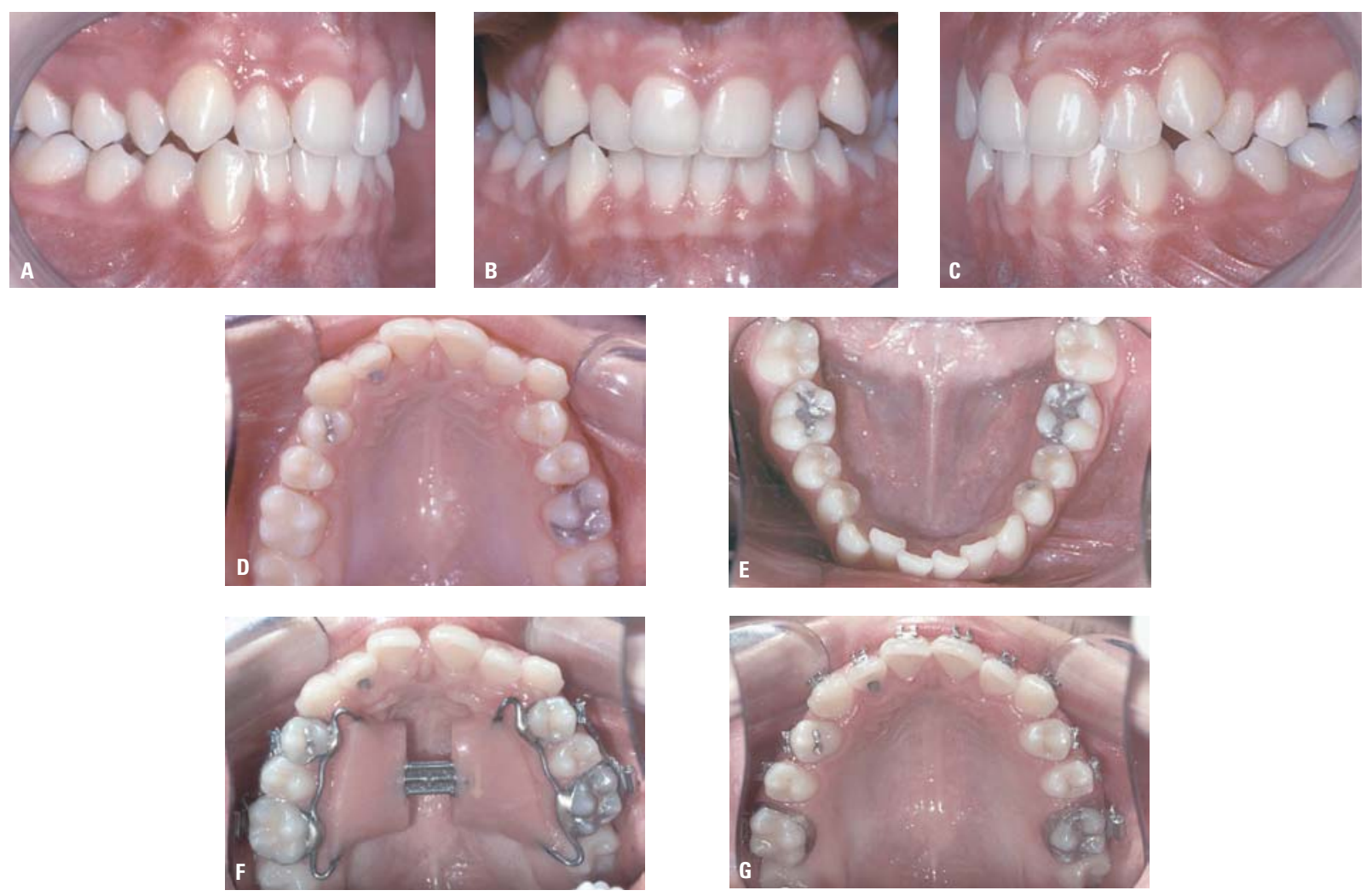

FIGURA 18 - Caso 5: má oclusão de Classe I com atresia de maxila e apinhamento. A-E) Caso inicial com apinhamento dentário e maxila atrésica. F, G) Disjunção maxilar com aparelho de Haas, seguida do uso de aparelho extrabucal cervical para ganho de espaço.

tro lado, é previsível que esta discrepância oclusal se estabeleça quando lançamos mão de exodontias no tratamento ortodôntico e quando estamos tratando pacientes com restaurações extensas, normalmente os adultos. O setup é o melhor meio de se avaliar previamente a desarmonia oclusal e a dificuldade a ser vencida para a intercuspidação, mas é na finalização do tratamento que precisa ser resolvida a maioria dos problemas.

Iniciamos este artigo considerando que o melhor ajuste oclusal é aquele estabelecido pelo movimento ortodôntico, devendo-se utilizar o desgaste seletivo como meio de tornar factível o movimento dentário. $\mathrm{O}$ discernimento entre o alcance da intercuspidação ideal com a mecânica ortodôntica unicamente, ou com auxílio do desgaste, depende do tipo de contato oclusal presente e daquele que se deve alcançar (Fig. 21). Portan- to, é imprescindível a leitura da oclusão antes de se iniciar o uso dos arcos retangulares, e antes de cada ativação deste arco.

Havendo se estabelecido o melhor alinhamento e nivelamento dos pontos de contato, e ainda faltando melhor intercuspidação, duas situações podem ser identificadas: (1) quando já existem dois tipos de contatos "A" e "B" ou "B" e "C", o movimento deve ser vertical, com desgaste em um ou ambos os dentes para permitir o movimento sem abertura da mordida anterior; (2) na presença de apenas um tipo de contato "A", "B" ou "C" deve-se incorporar torque aos arcos sem realizar desgastes. O discernimento de qual dente deve ser movimentado com torque, superior ou inferior, depende de outras avaliações: 2A) no caso de contato "A" ou "C" deve-se aumentar o torque do dente inferior, desde que haja boa espessura perio- 

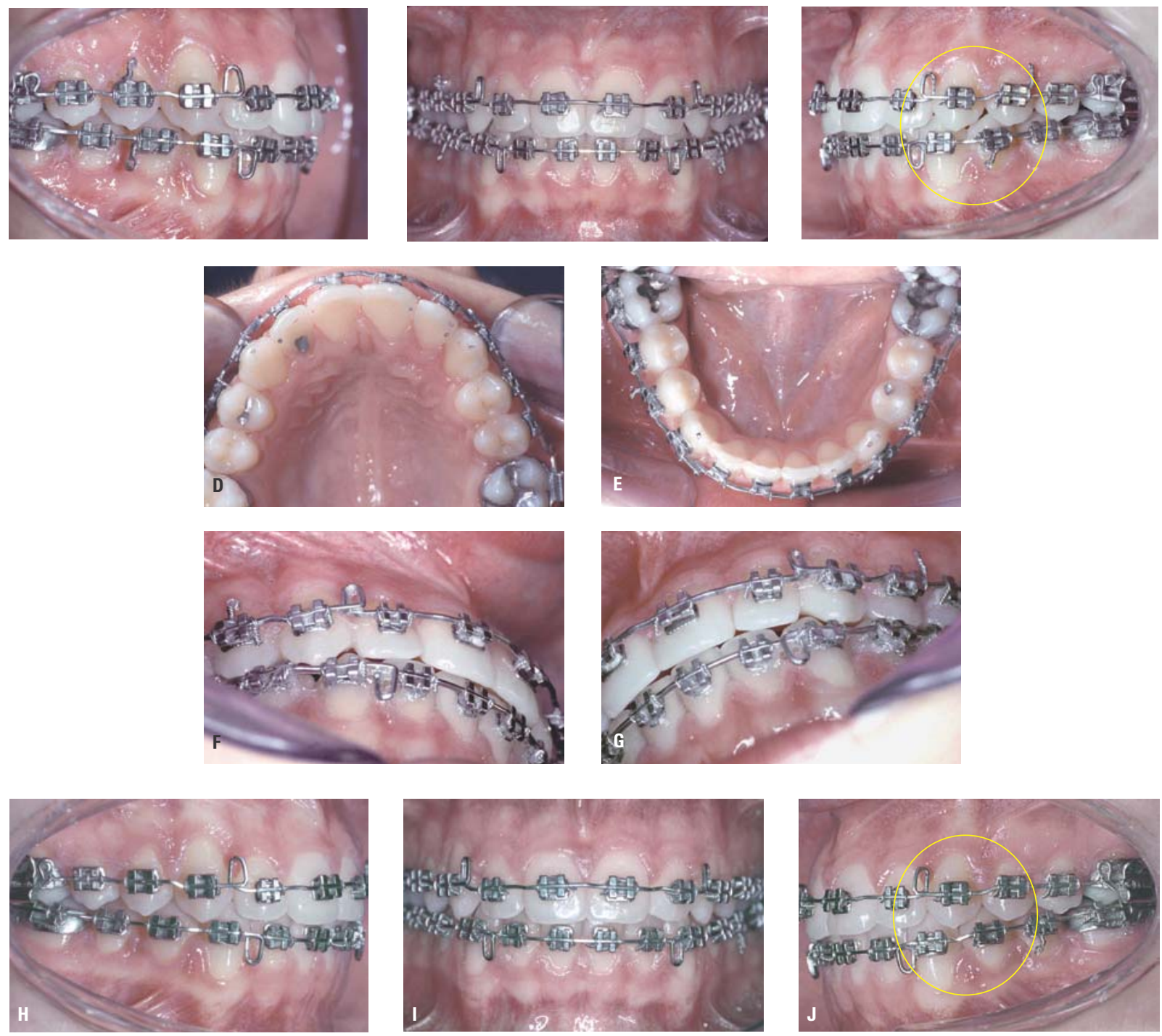

FIGURA 19 - Caso 5, continuação. A, B, C) Início da fase de finalização, com incorporação de degraus no arco associados a elásticos verticais, para melhora da intercuspidação em pré-molares e caninos. D, E, F, G) Checagem oclusal, contato dos caninos inferiores na crista marginal distal dos laterais, causando trauma oclusal e impedindo o movimento vertical planejado. H, I, J) Depois do desgaste seletivo o movimento foi rapidamente realizado, sem efeitos indesejáveis.

dontal, fazendo-se desgastes interproximais para evitar projeção dos dentes anteriores. No entanto, havendo risco periodontal, indica-se a inversão do torque superior (torque positivo); 2B) no caso de contato "B" apenas, deve-se aumentar o torque do dente superior, desde que não haja recessão periodontal, realizando desgaste interproximal para evitar que a diminuição do perímetro do arco gere aumento do overjet, 2C) no mesmo caso anterior, para controlar o risco periodontal da movimen- tação radicular superior para vestibular, pode-se inverter o torque inferior (Fig. 22-23).

Deve-se ter muito cuidado com os excessos. A intercuspidação de dentes posteriores não deve ser estabelecida à custa de desgastes oclusais amplos e indiscriminados. $\mathrm{O}$ ortodontista deve movimentar dentes até o limite da compatibilidade anatômica, evitando o ajuste por desgaste, que seria muito mais invasivo. Fechar mordida aberta ampla com ajuste oclusal é procedimento inaceitável, pois 

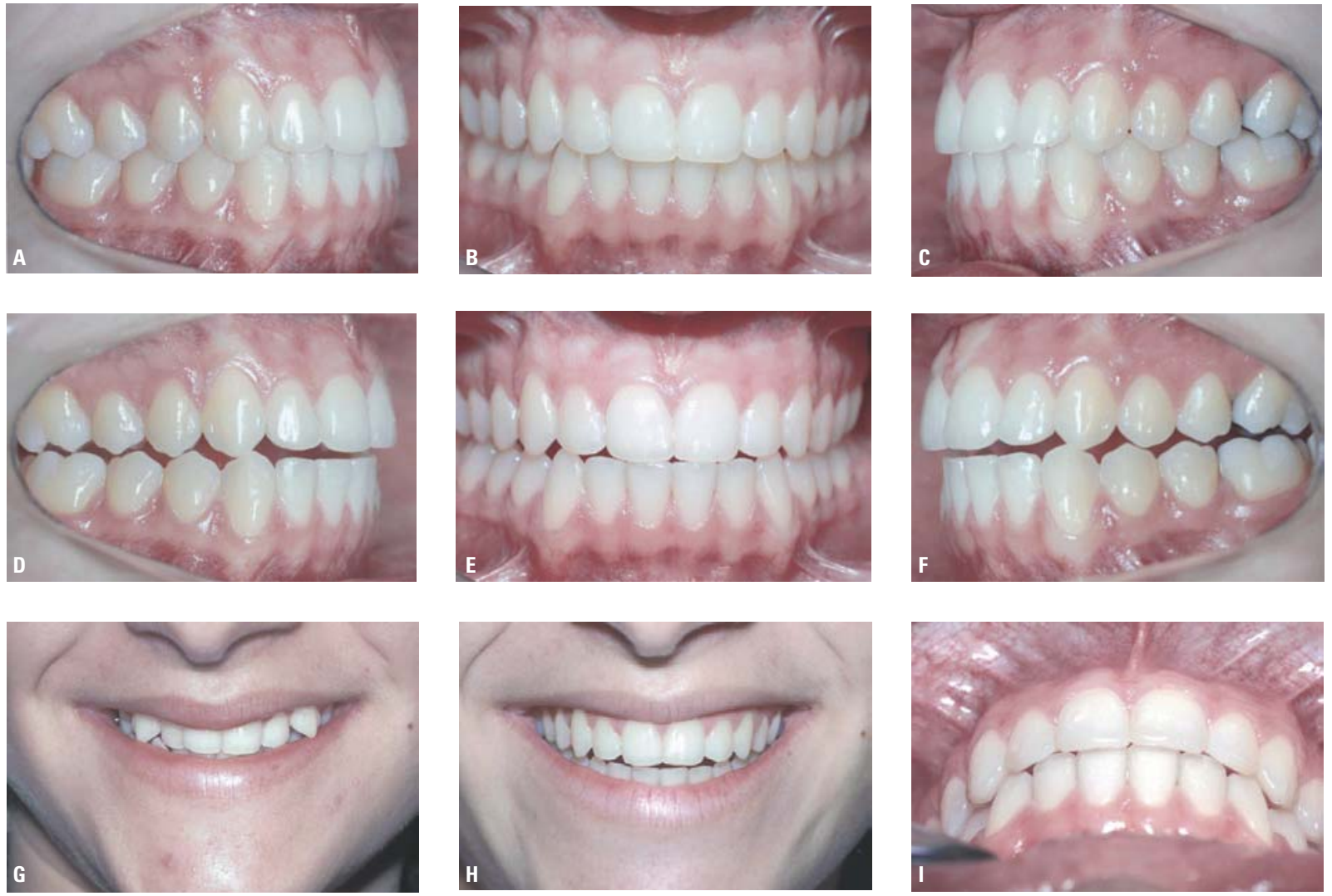

FIGURA 20 - Caso 5, continuação. A, B, C) Oclusão final com boa intercuspidação e boa saúde periodontal. D, E, F) Movimentos mandibulares bordejantes, com guia anterior e desoclusões direita e esquerda nos caninos. G, H, I) Melhora da estética do sorriso se comparados antes e depois, associado ao relacionamento oclusal ideal.
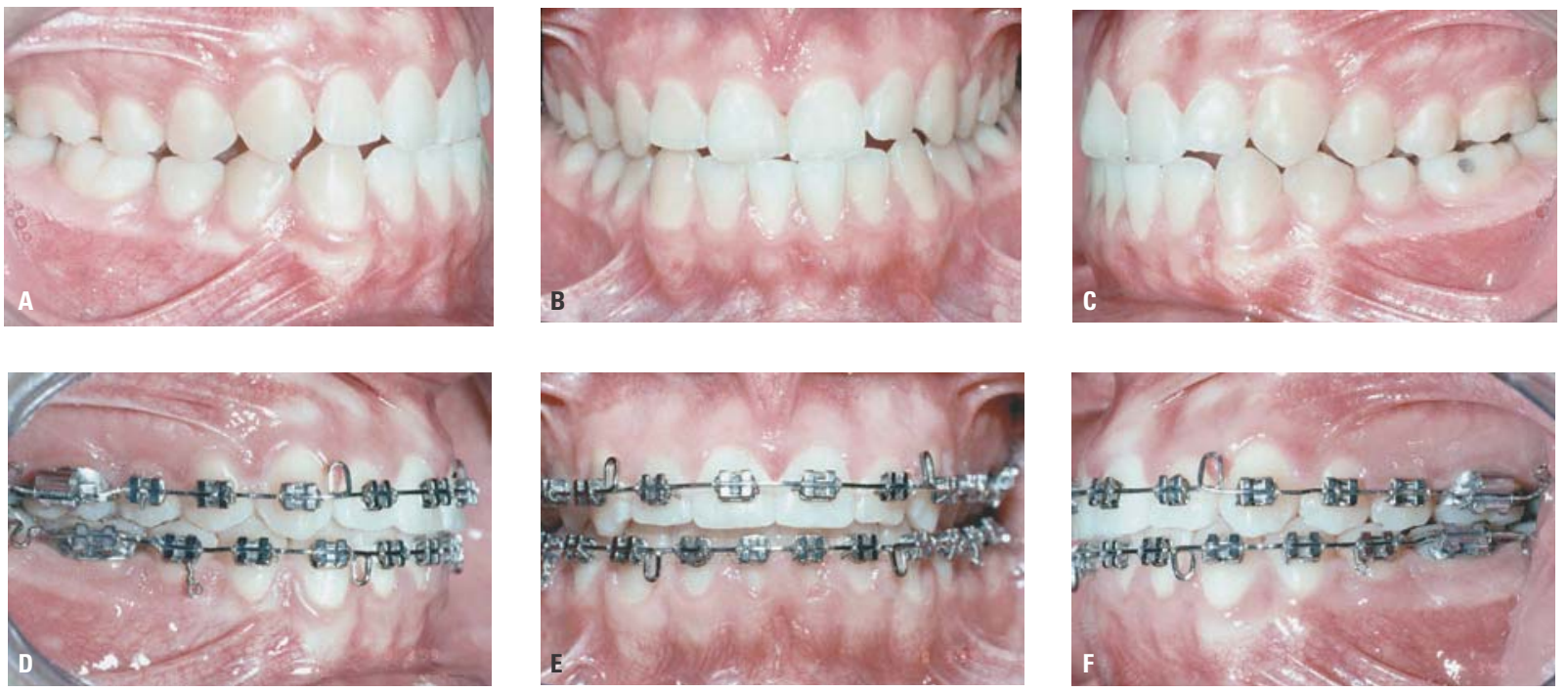

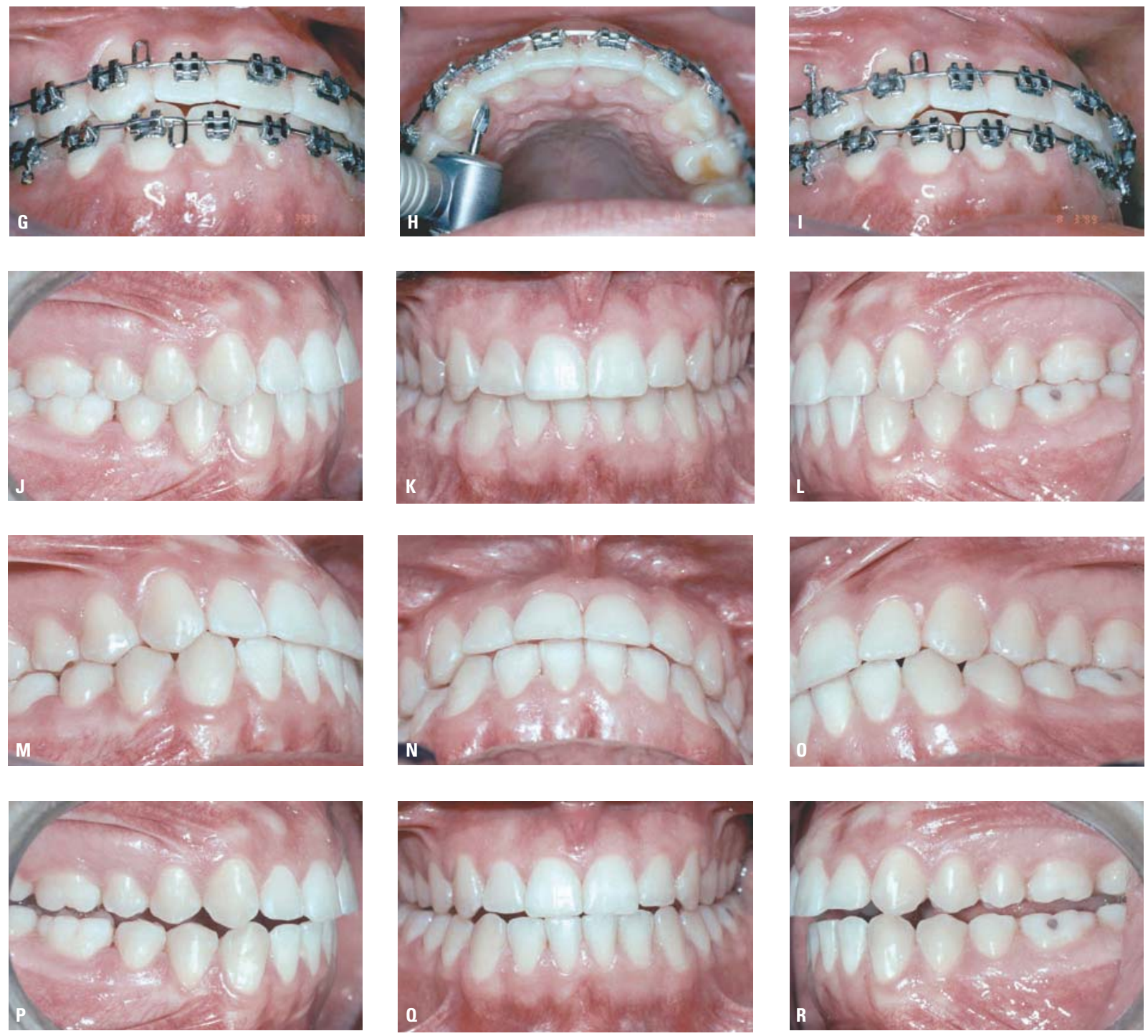

FIGURA 21 - Caso 6: má oclusão Classe III de Angle tratada por camuflagem. A, B, C) Caso inicial com mordida de topo anterior e desgastes incisais. D, E, F) Início da finalização depois de uso intenso de elásticos intermaxilares, necessitando de aumento da sobremorida. G, H, I) Verificação da interferência pela crista marginal mesial do canino superior ser volumosa, indicando desgaste seletivo para viabilizar o movimento dentário vertical. J, K, L) Caso final, com amplas compensações à desarmonia esquelética e intercuspidação satisfatória. M, N, 0) Vista dos encaixes das cúspides nos sulcos e fossas, e relacionamento incisal. P, 0, R) Movimentos mandibulares em oclusão mutuamente protegida.

além do risco de se gerar sensibilidade dentária, demonstra limitação profissional, que deve ser corrigida com a busca por maior conhecimento e melhor treinamento.

O principal conceito a ser incorporado no treinamento do ortodontista é que não existe arco ideal e nem prescrição ideal, dentre as inúmeras técnicas disponíveis na Ortodontia. Todas as pres- crições, inclusive o arco ideal da técnica Edgewi$\mathrm{se}^{11}$, são estabelecidas para médias e algumas variações de populações. A chance de um paciente se encaixar perfeitamente em todas as características médias é semelhante à de se acertar na loteria. Na finalização, o importante é a capacidade de enxergar o problema, conhecer a solução, dominar a técnica e o aparelho escolhido, intercuspidando 

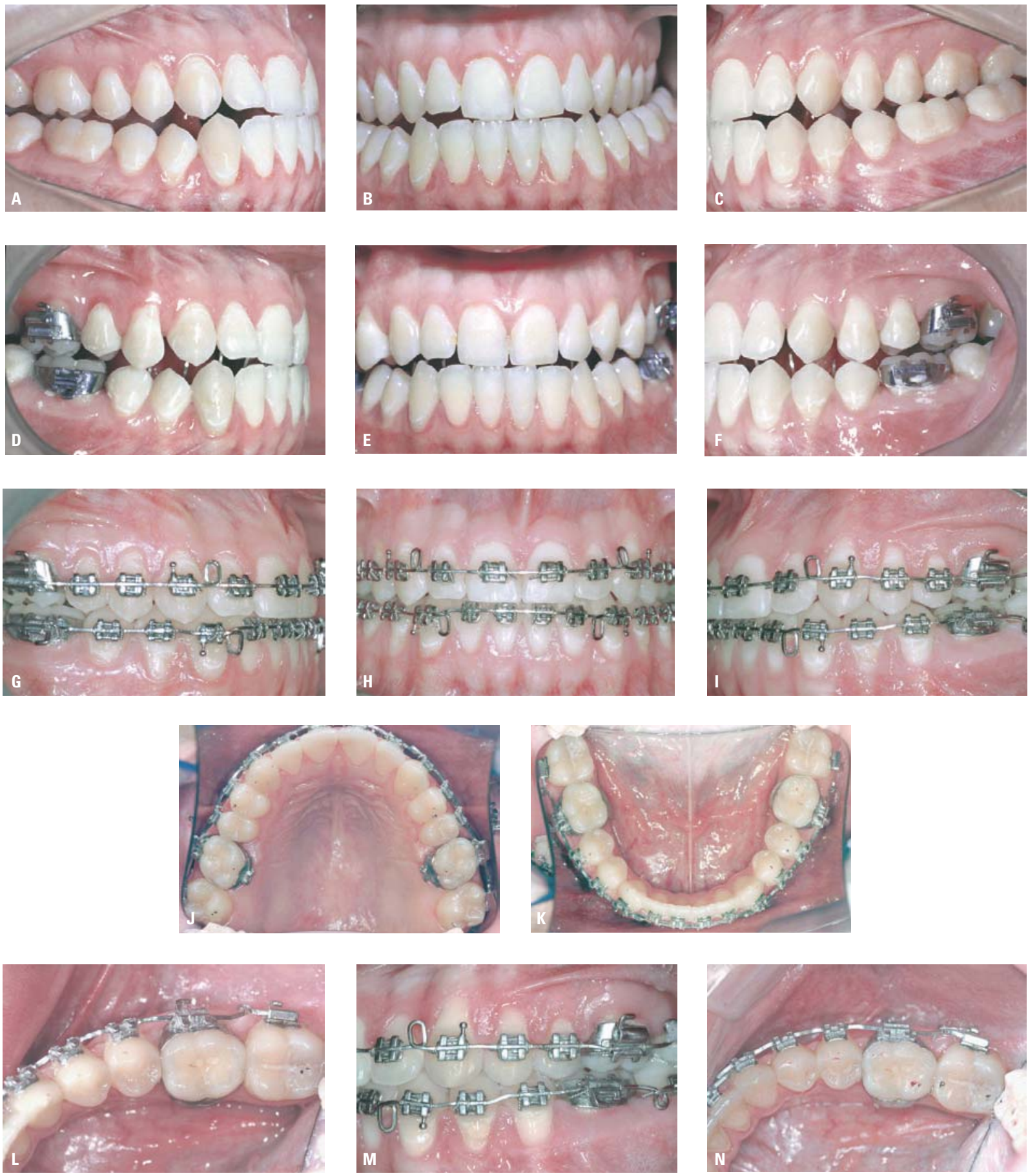

FIGURA 22 - Caso 7: paciente adulto, tratado com ampla compensação dentária e diferentes ações na finalização. A, B, C) Má oclusão Classe III com mordida aberta anterior e postura baixa da língua. D, E, F) Depois de expansão do arco superior, iniciando o uso de esporões soldados em arco lingual. G, H, I) Fase de finalização, com arcos retangulares e necessidade de melhora na intercuspidação posterior. J, K) Problemas diferentes detectados na análise oclusal: do lado esquerdo só há contato " $C$ ", o que demanda acentuar o torque inferior, e no lado esquerdo há contato " $B$ " e " $C$ ", indicando necessidade de desgaste e dobra em degrau no arco para extrusão superior. L, M, N) Desgaste dos contatos "B" e "C", realizados nas cúspides de contenção, pois estavam afastadas da ponta. Após alcançar a ponta deve-se desgastar o sulco central do antagonista, para que se estabeleçam novos contatos. 

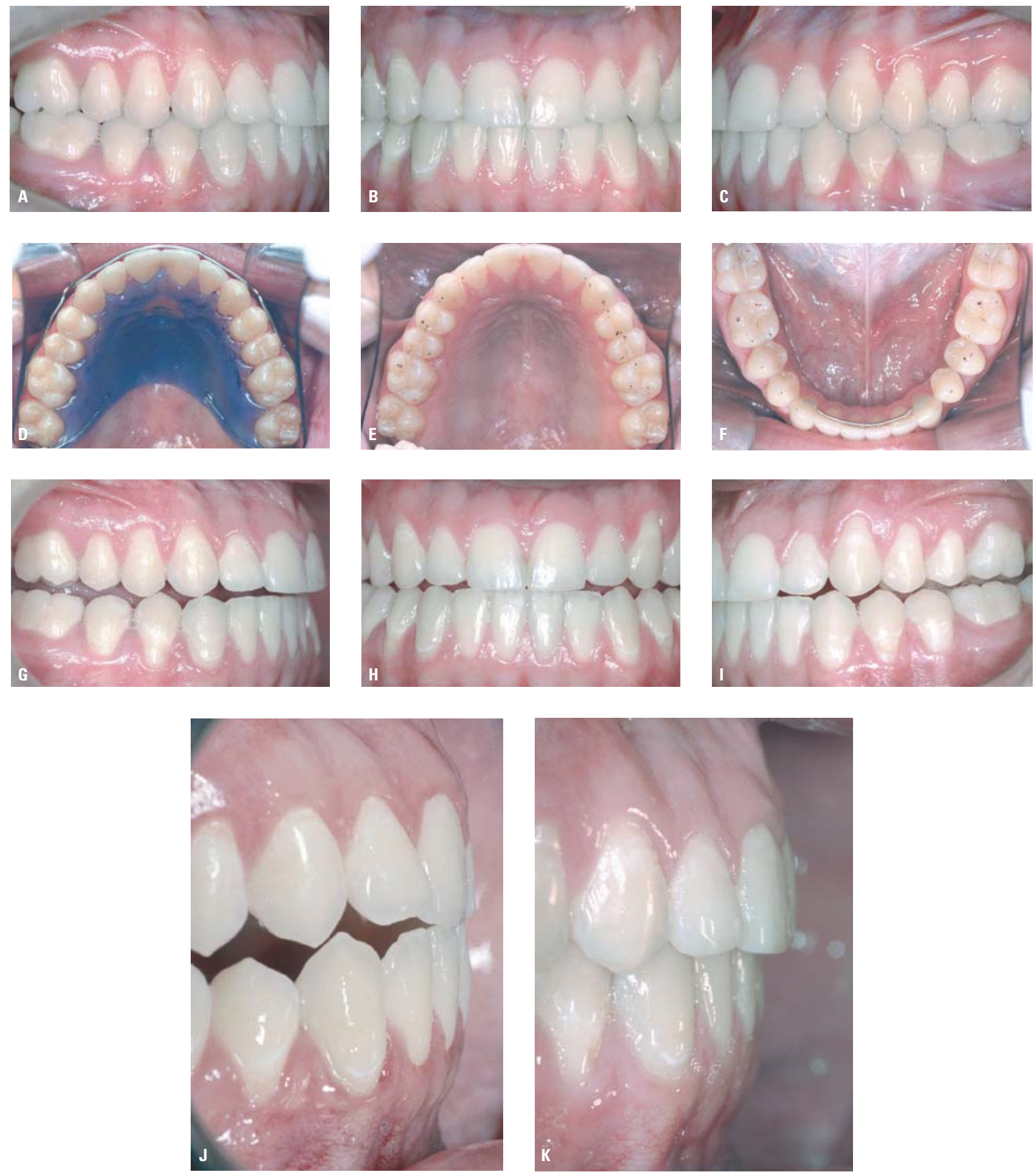

FIGURA 23 - Caso 7, continuação. A, B, C) Oclusão final com boa intercuspidação. D, E, F) Após o estabelecimento de contatos oclusais equilibrados, foi fornecida orientação para o uso somente noturno da placa de contenção. G, H, I) Movimentos mandibulares com guias anterior e em caninos direito e esquerdo. J, K) A evolução no estabelecimento da sobremordida pode ser vista na má oclusão inicial, e depois da terapia ortodôntica. 
os dentes de cada paciente.

$\mathrm{Na}$ maioria das vezes, os torques dos dentes posteriores estão excelentes no final do nivelamento, conseqüentemente, o arco retangular deveria estar passivo na região posterior. A ausência da leitura da oclusão faz com que estes arcos, quando ativos, gerem contatos prematuros com abertura de mordida, atrasando o tratamento e confundindo o profissional que se depara com um novo problema a tratar. Por este motivo, muitos ortodontistas simplesmente retiram o arco retangular de sua rotina clínica, perdendo uma ferramenta de precisão para a finalização do tratamento. É importante ressaltar que o arco retangular é solução e não problema, desde que seja realizada a correta leitura do seu futuro efeito antes que seja amarrado, o que demanda apenas alguma atenção. Neste momento, o profissional deve se fazer uma simples pergunta: quero mudar o torque dos dentes posteriores? A resposta deverá ser sim quando existir apenas um tipo de contato oclusal, sendo que a mudança no torque dos dentes posteriores estabelecerá um novo contato, equilibrando o sistema de forças e melhorando a posição da cúspide de contenção, para que esta se encaixe no dente antagonista. No entanto, na maioria das vezes a resposta será não, devendo-se retirar toda ativação do arco retangular. $\mathrm{O}$ uso automático de arcos em seqüência incorpora o erro sistemático, gerando aumento do risco periodontal conseqüente à associação do movimento radicular para vestibular com o trauma oclusal do contato prematuro.

\section{Após a Ortodontia}

Neste ponto, depois de todos os cuidados na finalização do tratamento ortodôntico, ainda resta a pergunta: o que falta para se alcançar as determinantes do equilíbrio oclusal? Normalmente muito pouco, pois ajustes oclusais por desgaste ou acréscimo não estão indicados como substitutos da Ortodontia ou como solução de problemas gerados durante o tratamento ortodôntico. O que se espera é um refinamento da oclusão, incorporando requintes de contatos oclusais e equilíbrio da potência dos contatos em $\mathrm{MIH}$, alcançando, conseqüentemente, a estabilização da oclusão e da posição mandibular.

Mais uma vez é importante ressaltar que a falta de contatos oclusais equilibrados pode não ser determinante para migrações dentárias indesejáveis, porque a quantidade de tempo e a intensidade da oclusão dos dentes são insuficientes para que o periodonto seja estimulado e permita a mudança de posição ${ }^{31}$. Por outro lado, episódios de apertamento dentário podem estabelecer tempo extra de contatos oclusais. Neste caso, as componentes horizontais causarão movimentos e seqüelas, especialmente após a suspensão do uso das contenções. Como o aparecimento das parafunções é imprevisível, ligada a fatores psicológicos, indicase o ajuste oclusal pós-Ortodontia como rotina de excelência e preocupação em longo prazo.

Considerando que interferências oclusais maiores foram eliminadas durante o procedimento ortodôntico, e aparelhos de contenção serão utilizados no final do tratamento, não se recomenda o ajuste imediatamente após a remoção dos aparelhos. Junte-se a isto a evidência de que há aumento da quantidade dos contatos oclusais após a remoção dos aparelhos, melhorando a qualidade do que se obteve com o procedimento ortodôntico $^{14,34}$. De fato, indicamos seis meses de espera como o melhor momento para o ajuste oclusal por desgaste pós-Ortodontia. Neste período, o uso de contenções é fundamental para contrapor pequenas interferências oclusais. $\mathrm{O}$ desenho do aparelho de contenção deve ser tal que não impeça o movimento vertical dos dentes posteriores, para maximizar os efeitos naturais da melhora da oclusão.

A diferença que a leitura oclusal e o desgaste seletivo pós-Ortodontia podem fazer para a estabilização dos resultados do tratamento está na comparação dos casos clínicos 3 e 8, expostos nas figuras 12-15 e 24-27, respectivamente. Quando o contato interferente é eliminado antes do efei- 
to indesejável, consegue-se um caso estável e sem seqüelas.

\section{COMO FAZER O AJUSTE OCLUSAL POR DESGASTE?}

Normalmente, este assunto é exposto em livros de Prótese Dentária, que minimizam ou negligenciam o movimento ortodôntico como técnica de ajuste oclusal ${ }^{8}$. De fato, algumas regras descritas em livros de oclusão devem ser aplicadas pelo movimento ortodôntico, e não por procedimentos protéticos ou por desgastes, como os autores suge$\mathrm{rem}^{8}$. Podemos trazer a regra dos terços para nossa expertise, adaptando ou aprimorando. Por exemplo, na técnica descrita por Okeson ${ }^{27}$, quando há contato da ponta da cúspide de contenção com o terço médio da vertente do antagonista há indica- ção de coroas protéticas para correção do contato. Neste caso, a Ortodontia elimina a mutilação do preparo para a coroa proposta porque a hipótese de haver contatos de ponta de cúspide distante de sulcos e fossas é eliminada durante a movimentação dentária. A Ortodontia só é incluída nos livros de Próteses e Oclusão quando, na regra dos terços, a ponta da cúspide de contenção contata próximo da ponta da cúspide do antagonista (Fig. 28). Nestes casos extremos sabemos que, provavelmente, para tratar o problema haveria necessidade de se incluir cirurgia ortognática ou distração osteogênica, ou os resultados seriam muito limitados.

Em consonância com a maioria dos autores $^{19,20,22,27}$, acreditamos que o ajuste por desgaste está indicado apenas quando a ponta da cúspide de contenção contata o terço mais próximo da
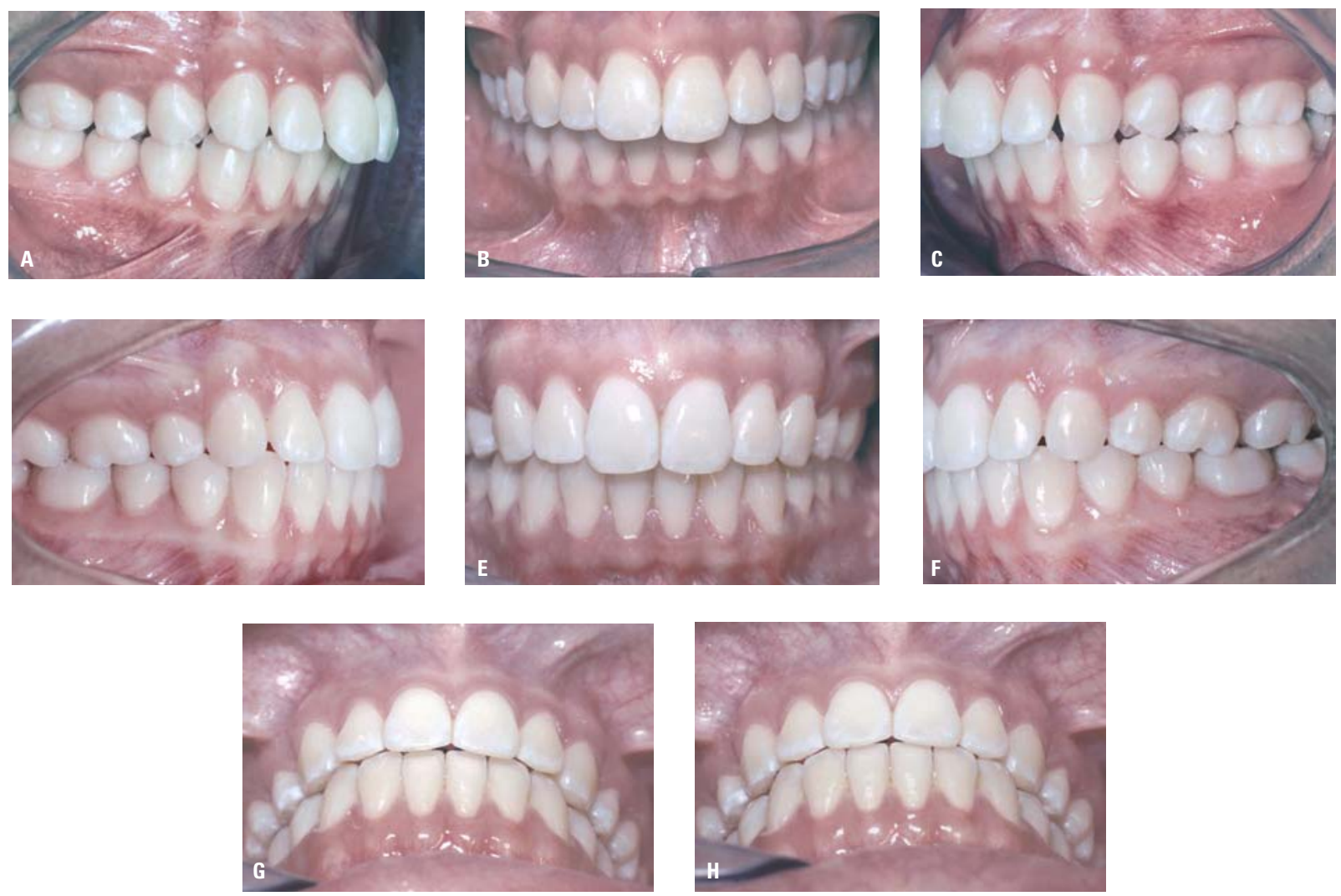

FIGURA 24 - Caso 8: Classe II, divisão 1, tratada - seguida de ajuste oclusal, com seqüência em articulador. A, B, C) Má oclusão inicial, com protrusão dentoalveolar superior. D, E, F) Paciente tratada com exodontias dos primeiros pré-molares superiores, alcançando bom resultado final. G, H) Seis meses depois do tratamento,o desvio de RC (G) para MIH (H) gerava contatos fortes entre os dentes anteriores em máxima intercuspidação, colocando em risco a estabilidade do tratamento. 

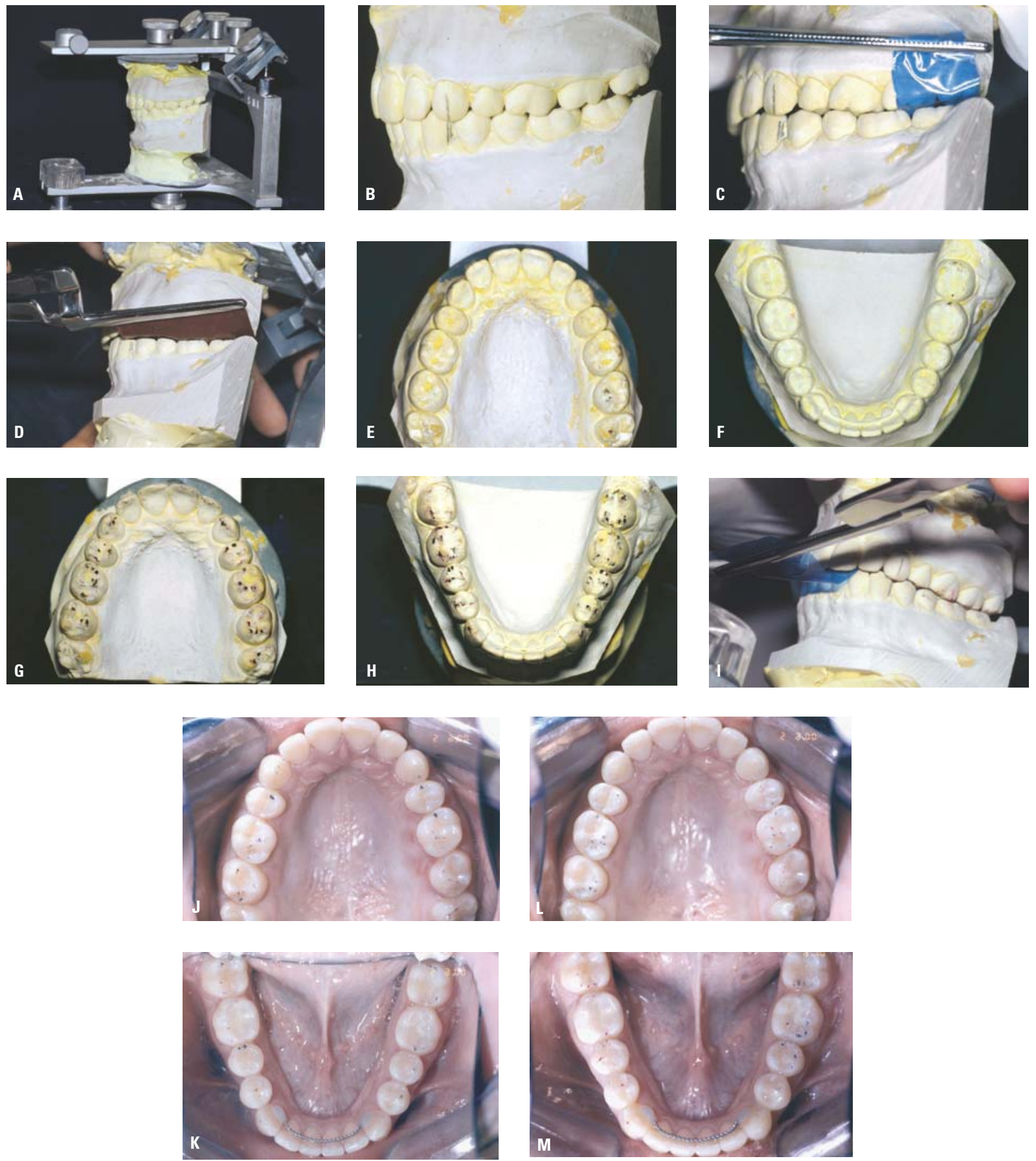

FIGURA 25 - Caso 8, continuação. A, B, C) A montagem em articulador mostra o desvio de 1mm de RC para MIH, dentro do aceitável se não houvesse sobrecarga na resultante de força na região anterior. D, E, F) Com fita AccuFilm II ${ }^{\circledR}$ foi verificado contato de "Equilíbrio" interferente nos molares do lado esquerdo. Deve-se remover os contatos, primeiro nas cúspides de contenção, para aproximá-los da ponta, e depois no dente antagonista estabelecendo fossas próximas aos sulcos. G, H, I) À medida que os contatos são removidos, novos contatos, em maior número, aparecem e passam a ser equilibrados. 0 limite é o toque dos dentes anteriores, que são distribuídos sem maiores desgastes. J, K, L, M) 0 desgaste é feito na boca, com reprodução inicial do que se fez nos modelos e, de novo, aumentando-se os contatos nos posteriores em RC, até que os contatos sobre os dentes anteriores apareçam e sejam equilibrados com menor potência. Como ocorreu boa distribuição de contatos e estabilização mandibular não houve necessidade de acréscimo por restaurações. 

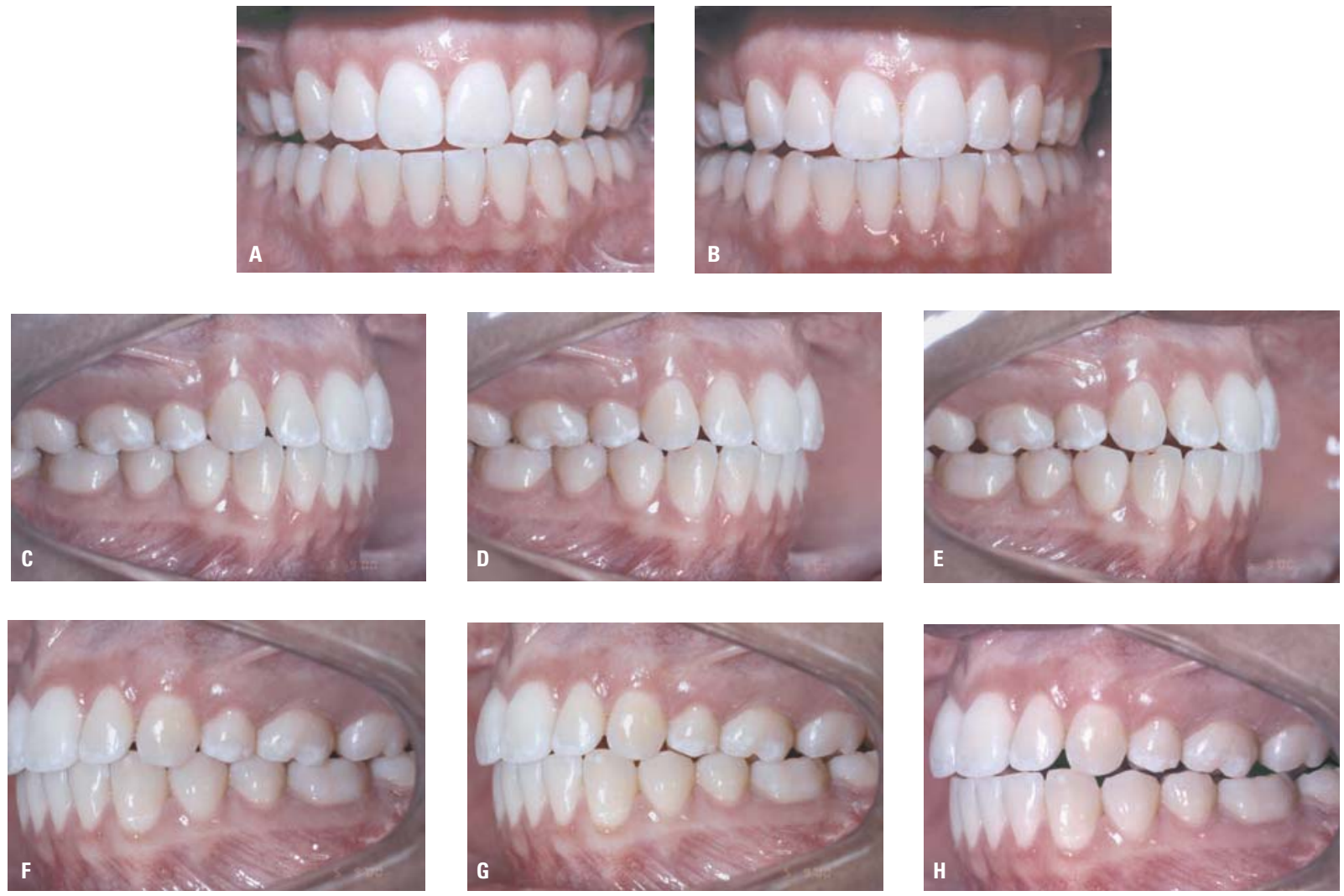

FIGURA 26 - Caso 8, continuação. A, B) A verificação em movimentos mostra o contato prematuro do incisivo central superior esquerdo no final da protrusiva. Foi realizado desgaste do bordo do incisivo superior para distribuição dos contatos nos incisivos. C, D, E) Lateralidade direita no início, meio e fim, com guia em caninos. F, G, H) Lateralidade esquerda em início, meio, até borda a borda.

fossa central do antagonista. Portanto, descreveremos a técnica de ajuste para esta situação, o que torna o procedimento muito mais simples e previsível.

Neste momento surge uma questão importante: devemos ou não montar em articulador os casos antes de executar o ajuste? A resposta é não, como rotina, pelo seguinte: (1) a montagem em articulador serve principalmente para se analisar a exigüidade do ajuste, com objetivo de alcançar estabilidade oclusal sem gerar sensibilidade ou risco pulpar pela extensão dos desgastes; (2) como base para visualização do local do dente a ser desgastado, a montagem em articulador perde o sentido, porque é improvável que o operador consiga realizar o mesmo procedimento em magnitude nos modelos de gesso e na boca do paciente. A res- posta será sim, se o intuito for de treinamento ou demonstração.

Por melhor que seja o ortodontista e seu esmero com a movimentação ortodôntica durante a finalização, a checagem oclusal revela, normalmente, três problemas comuns: (1) pequeno desvio para anterior da posição de RC para $\mathrm{MIH}$, que deve ser corrigido caso gere contatos fortes nos dentes anteriores; (2) contatos oclusais em magnitudes diferentes, considerando o tamanho da plataforma oclusal dos dentes, e os dois lados dos arcos dentários; (3) falta de alguns contatos necessários para o equilíbrio oclusal, e para estabilização mandibular. Todos estes determinantes da oclusão podem ser plenamente alcançados sem prolongar-se indefinidamente um tratamento ortodôntico.

O procedimento de ajuste por desgaste deve le- 

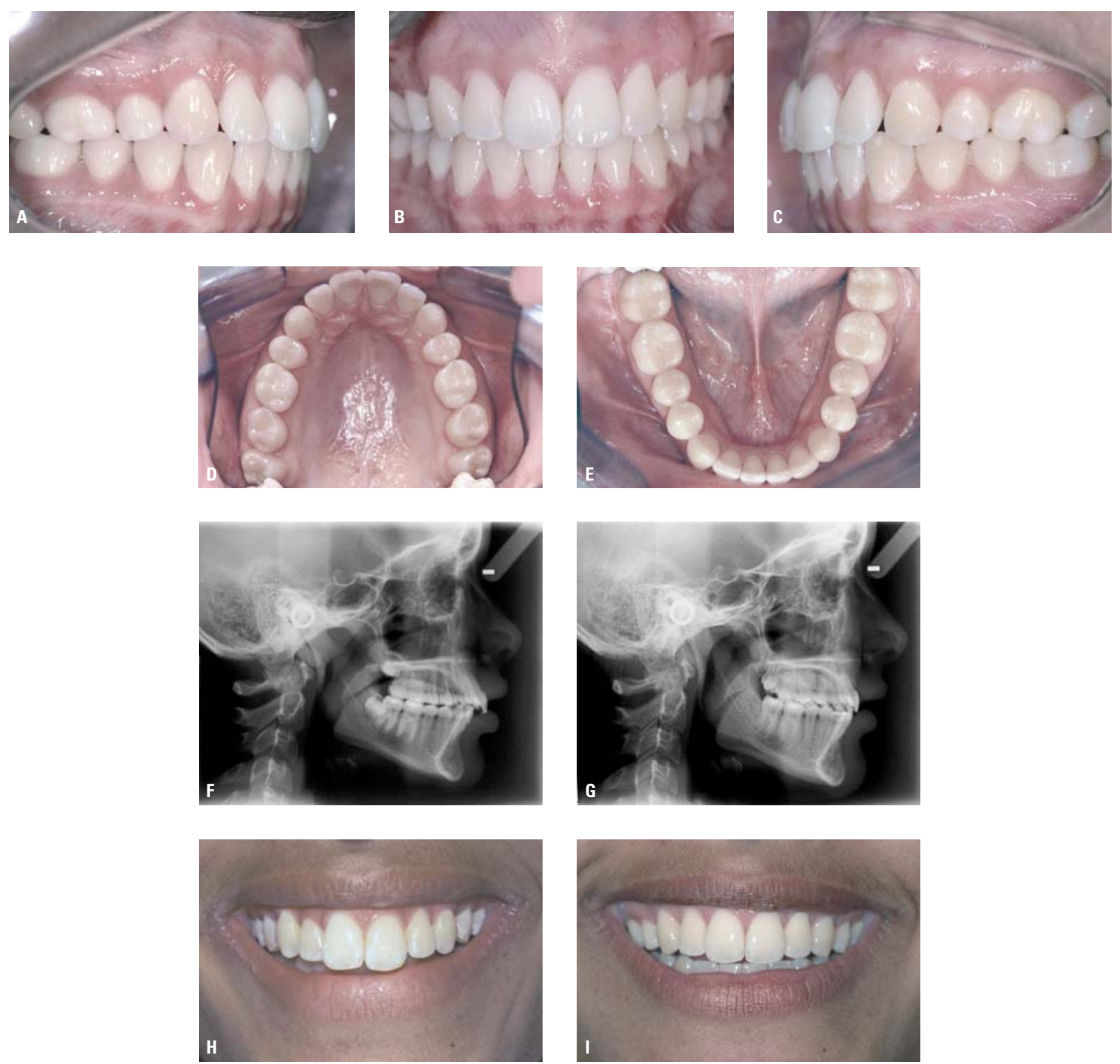

FIGURA 27 - Caso 8, continuação. A-E) Avaliação do caso depois de cinco anos sem contenção. F, G) Radiografias cefalométicas de perfil antes e depois do tratamento. H, I) Estética do sorriso antes do tratamento e no pós-contenção, respectivamente.

var, em média, entre 10 e 20 minutos, utilizandose inicialmente brocas diamantadas esféricas ou em forma de torpedo de tamanho médio, seguidas de brocas multilaminadas (12 lâminas) com a mesma forma e tamanho, e finalizado com borrachas abrasivas e pasta de polimento (Fig. 29). Papel articular de precisão (Accufilm II ${ }^{\circledR}$ ) deve ser utilizado na checagem dos contatos entre os dentes antagonistas antes de cada procedimento.
Como regras básicas para o procedimento de ajuste por desgastes, podemos descre$\operatorname{ver}^{8,9,18,19,20,28,41}$ :

1) Deve-se manipular o paciente em RC. Se houver um pequeno desvio para $\mathrm{MIH}$ sem contatos fortes nos dentes anteriores, pode-se fazer o ajuste dos contatos na posição de $\mathrm{MIH}$. Caso o desvio mandibular gere forças horizontais, especialmente com frêmito, o procedimento deverá 
ser realizado na posição de RC.

2) Normalmente os contatos dos dentes posteriores possuem magnitudes diferentes. Logo, devem-se desgastar os de maior intensidade para obtenção de contatos bilaterais simultâneos e eqüipotentes.

3) No caso de ajuste em RC, uma tira de papel celofane ajuda a encontrar o quadrante do primeiro contato, que o prende e rasga facilmente.

4) Deve-se fazer o desgaste da cúspide de contenção até que o contato esteja bem próximo de sua ponta, a partir daí o procedimento é realizado no dente antagonista, aplainando a base de uma cúspide, aprofundando uma fossa ou diminuindo a saliência de cristas marginais.

5) Para cada dente, o ajuste deve buscar o aumento do número de contatos oclusais, com no mínimo um contato "A" e um contato "B", ou um contato "B" e um contato "C" para estabilização no sentido vestibulolingual. Da mesma forma, em cada dente deve haver um contato de parada e um contato de equilíbrio, para estabilização dentária e mandibular no sentido mesiodistal.

6) À medida que desgastes são realizados, aumenta-se o número de contatos oclusais, o que é desejável, podendo levar potencialmente ao estabelecimento de todos os tipos de contatos para o equilíbrio oclusal, em todos os dentes.

7) Existe um limite para os desgastes oclusais. Este momento é definido pelo contato nos dentes anteriores, pois estes aceitam pouco ajuste devido à espessura de esmalte e necessidade de controle da dimensão vertical do paciente. A maior

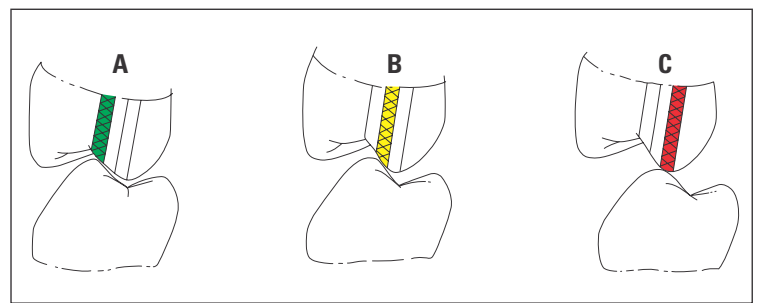

FIGURA 28 - Regra dos terços, que divide a vertente interna da cúspide de contenção em três partes, encontrada nos livros de Prótese, é revisada. A) Quando a ponta da cúspide de contenção toca no terço mais próximo do sulco central indica-se o ajuste oclusal, e isto é consensual. B) Quando a ponta da cúspide contata o terço médio, os livros de Prótese indicam coroas ou próteses fixas, quando a Ortodontia deveria ser a melhor solução. C) Só quando a ponta da cúspide de contenção contata o terço mais próximo da ponta da cúspide do antagonista, os livros de Oclusão indicam a Ortodontia, quando na verdade tratar-se-ia de caso cirúrgico.

potência dos contatos deverá estar nos dentes posteriores para evitar movimentações para vestibular dos dentes anteriores. Para esta avaliação uma tira de papel celofane deve passar entre os incisivos sem rasgar.

8) A partir dos contatos dos dentes anteriores, o aumento dos contatos posteriores na nova $\mathrm{MIH}$, se necessário, deverá ser feito por acréscimo de material restaurador ou prótese.

9) Durante a excursão mandibular em protrusiva, o papel articular deve marcar os seis dentes anteriores no início do movimento, havendo a prevalência dos contatos nos incisivos centrais superiores com os quatro incisivos inferiores, do meio até o final da movimentação, borda a borda. Para a obtenção da oclusão mutuamente protegida, não deve haver interferências nos dentes posteriores durante o movimento. O contato dos dentes an-
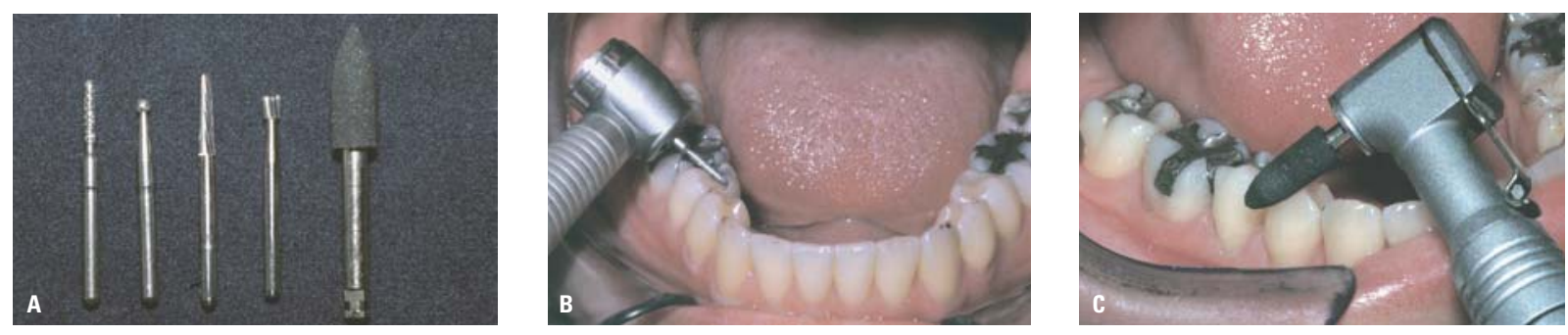

FIGURA 29 - Procedimentos de desgaste seletivo. A) Seqüência de brocas: diamantadas, carbide 12 lâminas e borracha abrasiva. B) Uso de broca diamantada troncocônica em alta rotação. C) Borracha abrasiva no micro-motor começando o acabamento, seguido de pasta de polimento e taça de borracha. 
teriores provoca alto nível de inibição muscular, protegendo o sistema estomatognático ${ }^{41}$.

10) Normalmente a interferência em protrusão deve-se ao contato da vertente distal da cúspide vestibular superior com a ponta da cúspide vestibular inferior. Neste caso, desgasta-se o dente superior, eliminando o problema pelo ajuste na cúspide não funcional (vestibular superior), preservando a de contenção (vestibular inferior). Se o contato for entre as duas vertentes desgasta-se ambas, preservando os contatos em RC na cúspide de contenção. Este problema pode ser evitado aumentando-se a sobremordida durante o tratamento ortodôntico, extruindo dentes anteriores. O discernimento entre atuar no arco superior ou no inferior deve ser baseado no efeito estético: (a) a extrusão deve ser dos dentes superiores se for desejável o aumento de exposição destes dentes na fala e no sorriso, (b) a decisão pela extrusão dos inferiores deve ser tomada quando a posição dos incisivos superiores estiver agradável.

11) No movimento de lateralidade, o mais comum e mais fácil é a obtenção da guia canina, quando apenas os caninos mantêm o contato, gerando a desoclusão dos dentes posteriores.

12) Muito cuidado deve ser tomado, especialmente em cúspides salientes de dentes posteriores, pois a extrusão dos caninos para obtenção da guia canina pode gerar o aspecto vampiresco, com prevalência destes dentes na curva do sorriso, quando deveria haver prevalência dos incisivos centrais. Portanto, quando se estabelece naturalmente a função em grupo, após o nivelamento dos pontos de contato dos dentes posteriores e da conformação estética dos dentes anteriores, esta deve ser refinada para que os contatos nos dentes posteriores no lado de trabalho sejam progressivamente menores no sentido posterior.

13) Quando existe interferência posterior no lado de trabalho, deve-se desgastar a ponte da cúspide de não-contenção, vestibular superior ou lingual inferior.

14) Para qualquer situação, os dentes posteriores do lado de não-trabalho devem estar sem contato durante todo o movimento de lateralidade.

15) Definitivamente, a interferência no lado de não-trabalho deveria ser eliminada durante o tratamento ortodôntico, pois envolve as cúspides de contenção dos dentes antagonistas (vestibulares inferiores com palatinas superiores). No entanto, persistindo o contato após a Ortodontia, este deverá ser identificado em MIH com o papel articular no lado preto e no movimento com o lado vermelho. Desgasta-se, então, a ponta da cúspide cujos contatos - "A" e "B" do dente inferior, ou "B" e "C" do dente superior - estiverem mais afastados dela, buscando preservar ambos os contatos nos dois dentes. Se isso não for possível com o ajuste por desgaste, o retratamento ortodôntico está indicado.

É importante que o ortodontista tenha treinamento específico, antes de lançar mão do uso de desgastes seletivos como rotina. $\mathrm{O}$ aprendizado deve iniciar em modelos de gesso montados em articuladores semi-ajustáveis como simulador, pois parece ser o melhor caminho para se visualizar os efeitos dos desgastes. Conhecimento e treinamento associados preparam o profissional para reconhecer limites e verificar os objetivos alcançados. Mesmo para aqueles que preferem solicitar o ajuste por desgaste a outros especialistas, são co-responsáveis pelo procedimento, devendo considerá-lo complementar e não substituto da Ortodontia. Talvez a afirmação de Peter E. Dawson ${ }^{9}$ - "realizar um procedimento insatisfatório de desgaste seletivo é pior do que deixar uma má oclusão" - devesse ser estendida ao ajuste oclusal feito através da Ortodontia.

\section{CONCLUSÃO}

O ajuste oclusal não está indicado como substituto do movimento dentário, nem como solução para as limitações do ortodontista. Por outro lado, o procedimento é determinante para diminuir o tempo de tratamento, tornando factível um movimento dentário desejado, evitando muitas se- 
qüelas de trauma oclusal estabelecidas durante o tratamento ortodôntico. Uma leitura da oclusão, através de papel de checagem oclusal, é imprescindivel para se verificar que tipo de movimento deve ser realizado e se este é exeqüível, principalmente antes da instalação ou ativação de arcos retangulares. Desgastes oclusais para correção de discrepâncias anatômicas durante a Ortodontia aceleram a movimentação dentária e melhoram a intercuspidação, por promoverem melhora da forma dos dentes antagonistas. Um refinamento dos contatos oclusais após o tratamento ortodôntico diminui o efeito deletério das parafunções, que podem aparecer a qualquer tempo. $\mathrm{O}$ ajuste por desgaste deve ser realizado seis meses após a Ortodontia para corrigir pequenos erros e promover melhor estabilidade oclusal e mandibular, estabelecendo contatos "A", "B", "C", de "parada" e de "equilíbrio", bem distribuídos. Ao final do procedimento deve haver máxima distribuição de contatos em MIH; carga axial ou quase axial; plano oclusal, dimensão vertical e espaço livre funcional, aceitáveis; e contatos que permitam livre fechamento e movimentos excursivos sem interferência $^{22}$. O principal objetivo do ajuste é minimizar o uso de contenções, a partir do alcance do equilíbrio oclusal. Nunca é demais salientar que não pode existir a certeza do alcance da estabilidade dos resultados do tratamento só pelo equilíbrio oclusal. Para tanto, haveria também a necessidade da existência da normalidade muscular associada à saúde periodontal.

\section{AGRADECIMENTOS}

Os autores gostariam de agradecer ao Dr. Paulo Isaias Seraidarian, ao Dr. Marcio Bittencourt e à Dra. Telma Martins de Araújo, pela ajuda na elaboração deste Tópico Especial.

Occlusal adjustment in Orthodontics: why, when and how?

\begin{abstract}
Introduction: The knowledge of dental occlusion should be considered the basic foundation to an excellent orthodontic practice. The patient's diagnose without the centric relation assessment can take the orthodontist to an unpleasant surprises. The use of rectangular archwires requires occlusal contacts been checked to decide what kind of the dental movement will be necessary to achieve the dental equilibrium and mainly to investigate if the movement will be possible. Considering the occlusal surfaces complexity, the occlusal adjustment by selective grinding should be performed during the orthodontic treatment to allow vertical dental movements reducing treatment's time. Occlusal interferences are responsible not only for biomechanics adverse effects, producing undesirable dental movements, but also for potential side effects such as excessive forces (occlusal trauma), leading to roots reabsorption. The occlusal adjustment is a determinant point on dental balance after the end of orthodontics treatments, where each posterior occlusal tooth contacts " $\mathrm{A}$ " and " $\mathrm{B}$ ", or " $\mathrm{B}$ " and " $\mathrm{C}$ " on buccolingual aspect, as well as the stoppers and equalizers contacts on mesiodistal direction must be achieved and well established. The appropriate role of anterior teeth in mandibular movements must be determined, allowing immediate disclusion of posterior teeth, known as anterior guide, and promoting protecting muscle forces to the stomatognathic system. Selective grinding should not be used in place of well planned and executed orthodontic movement. Aim: The aim of this article is to present the rationale use of occlusal adjustment in Orthodontics.
\end{abstract}

Key words: Occlusal adjustment. Orthodontic. Selective grinding. Occlusal equilibrium. Dental stability. 


\section{REFERÊNCIAS}

1. BEYRON, H. L. Occlusion: point of significance in planning restorative procedures. J. Prosthet. Dent., St. Louis, v. 30 no. 4, p. 641-652, Oct. 1973

2. BOLTON, W. A. Disharmony in tooth size and its relation to the analysis and treatment of malocclusion. Angle Orthod., Appleton, v. 28, no. 3, p. 113-130, July 1958.

3. BONDEMARK, L.; HOLM, A. K.; HANSEN, K.; AXELSSON, S.; MOHLIN, B.; BRATTSTROM, V.; PAULIN, G.; PIETILA, T. Longterm stability of orthodontic treatment and patient satisfaction: a systematic review. Angle Orthod., Appleton, v. 77, no. 1, p. 181-191, Jan. 2007.

4. BOUCHER, C. O. Swenson's complete dentures. 6th. ed. St. Louis: Mosby, 1970.

5. BURSTONE, C. J.; KOENIG, H. A. Force systems from an ideal arch. Am. J. Orthod. Dentofacial Orthop., St. Louis, v. 65 , no. 3, p. 270-289, Mar. 1974

6. BURSTONE, C. J. Perspectiva da estabilidade em Ortodontia. In: NANDA, R.; BURSTONE, C. J. Contenção e estabilidade em Ortodontia. São Paulo: Paramenicana, 1995. p. 36-48.

7. BUTLER, J. A.; ZANDER, H. A. Evaluation of two occlusal concepts. Parodontol. Acad. Rev., Zurich, v. 2, no. 1, p. 5-19, Mar. 1968

8. DAWSON, P. E. Avaliação, diagnóstico e tratamento dos problemas oclusais. St. Louis: C. V. Mosby, 1980.

9. DAWSON, P. E. Oclusão funcional: da ATM ao desenho do sorriso. St. Louis: C. V. Mosby, 2008.

10. DE FREITAS, K. M.; JANSON, G.; DE FREITAS, M. R.; PIZAN, A.; HENRIQUES, J. F.; PINZAN-VERCELINO, C. R. Influence of the quality of the finished occlusion on post-retention occlusal relapse. Am. J. Orthod. Dentofacial Orthop., St. Louis, v. 132, no. 4, p. 428, Oct. 2007.

11. DEWEL, B. F. The clinical application of the Edgewise appliance in Orthodontic treatment. Am. J. Orthod. Dentofacial Orthop., St. Louis, v. 42, no. 1, p. 4-28, Jan. 1956

12. FORSSELL, H.; KALSO, E. Application of principles of evidencebased medicine to occlusal treatment for temporomandibular disorders: are there lessons to be learned? J. Orofac. Pain, Carol Stream, v. 18, no. 1, p. 9-32, Winter 2004.

13. GRABER, T. M. The "three M's": muscles, malformation, and malocclusion. Am. J. Orthod. Dentofacial Orthop., St. Louis, v. 49, no. 6, p. 418-450. June 1963.

14. HAYDAR, B.; CIGER, S.; SAATCI, P. Occlusal contact changes after the active phase of orthodontic treatment. Am. J. Orthod. Dentofacial Orthop., St. Louis, v. 102, no. 1, p. 22-28, July 1992.

15. HUANG, G. J. Occlusal adjustment for treating and preventing temporomandibular disorders. Am. J. Orthod. Dentofacial Orthop., St. Louis, v. 126, no. 2, p. 138-139, 2004.

16. $\mathrm{KOH}, \mathrm{H} . ; \mathrm{ROBINSON}, \mathrm{P} . \mathrm{G}$. Occlusal adjustment for treating and preventing temporomandibular joint disorders. J. Oral Rehabil., Oxford, v. 31, no. 4. p. 287-292, Apr. 2004.

17. MATTOS, A. M.; BRANDÃO, R. C. B. Uma nova proposta de classificação das mordidas cruzadas posteriores. Rev. ABO Nac., São Paulo, v. 15, n. 1, p. 54-60, fev./mar. 2007.

18. McCOLLUM, B. B.; EVANS, R. L. The gnathological concepts of Charles E. Stuart, Beverly B. McCollum and Harvey Stallard. Georgetown Dent. J., Washington, D. C., v. 36, no. 1, p. 12-20, Winter 1970.

19. McHORRIS, W. H. Occlusion with particular emphasis on the functional and parafunctional role of anterior teeth - Part 2. J. Clin. Orthod., Boulder, v. 13, no. 10, p. 684-701, Oct. 1979.

20. McHORRIS, W. H. Occlusion with particular emphasis on the functional and parafunctional role of anterior teeth - Part 1. J. Clin. Orthod., Boulder, v. 13, no. 9, p. 606-620, Sept. 1979.

21. McNAMARA JR., J. A.; SELIGMAN, D. A.; OKESON, J. P. Occlusion, orthodontic treatment, and temporomandibular disorders: a review. J. Orofac. Pain, Carol Stream, v. 9, no. 1, p. 73-90, Winter 1995.
22. McNEILL, C. Selective tooth grinding and equilibration. In: McNEILL, C. Science and practice of occlusion. Carol Stream: Quintessence, 1997. p. 404-420.

23. MOHL, N. D. et al. Fundamentos de oclusão. Chicago: Quintessence, 1989

24. MONNERAT, C.; MUCHA, J. N. Ortodontia - oclusão estabilidade. Rev. Dental Press Ortodon. Ortop. Facial, Maringá, v. 5, n. 1, p. 32-44, jan./fev. 2000

25. MOYERS, R. E. Ortodontia. 4. ed. Rio de Janeiro: Guanabara Koogan, 1991.

26. MULLIGAN, T. F. Common sense mechanic: static equilibrium. J. Clin. Orthod., Boulder, v. 13, no. 11, p. 762-766, Nov. 1979

27. OKESON, J. P. Tratamento das desordens temporomandibulares e oclusão. 4. ed. São Paulo: Artes Médicas, 2000.

28. OKESON, J. P. Critérios para uma oclusão funcional ideal. In: OKESON, J. P. Tratamento das desordens temporomandibulares e oclusão. 4. ed. São Paulo: Artes Médicas, 2000. p. 87-100.

29. PROFFIT, W. R. The facial musculature in its relation to the dental occlusion. In: CARLSON, D. S.; McNAMARA JR., J. A. Muscle adaptation in the craniofacial region. Michigan: CHGD, 1978. p. 73-89

30. PROFFIT, W. R.; FIELDS JR., H. W. Ortodontia contemporânea. 2. ed. Rio de Janeiro: Guanabara Koogan, 1995.

31. PROFFIT, W. R.; FIELDS JR., H. W.; SARVER, D. M. Ortodontia contemporânea. 4. ed. Rio de Janeiro: C. V. Mosby, 2007.

32. RAMFJORD, S. P. Dysfunctional temporomandibular joint and muscle pain. J. Prosthet. Dent., St. Louis, v. 11, p. 353-374, 1961.

33. RAMFJORD, S. P. Bruxism: a clinical and eletromyographic study. J. Am. Dent. Assoc., Chicago, v. 62, p. 21-44, Jan. 1961.

34. RAZDOLSKY, Y.; SADOWSKY, C.; BeGOLE, E. A. Occlusal contacts following orthodontic treatment: a follow-up study. Angle Orthod., Appleton, v. 59, no. 3, p. 181-186, 1989.

35. ROTH, R. H. Gnathological views and aims in orthodontic treatment. Inf. Orthod. Kieferorthop., München, v. 5, no. 4, p. 323-338, 1973.

36. ROTH, R. H. Functional occlusion for the orthodontist. J. Clin. Orthod., Boulder, v. 15, no. 1, p. 32-51, Jan. 1981.

37. SADOWSKY, C.; POLSON, A. M. Temporomandibular disorders and functional occlusion after orthodontic treatment: results of two long-term studies. Am. J. Orthod. Dentofacial Orthop., St. Louis, v. 86, no. 5, p. 386-390, Nov. 1984.

38. SCHUYLER, C. H. Freedom in Centric. Dent. Clin. North Am., Philadelphia, v. 13, no. 3, p. 681-686, July 1969.

39. SHELLHART, W. C. Equilibrium Clarified. Am. J. Orthod. Dentofacial Orthop., St. Louis, v. 108, no. 4, p. 394-401, Oct. 1995.

40. SONDHI, A. Anterior interferences: their impact on anterior inclination and orthodontic finishing procedures. Semin. Orthod., Philadelphia, v. 9, no. 3, p. 204-215, Sept. 2003.

41. SPEAR, I. M. Fundamental occlusal therapy considerations. In: McNEILL, C. Science and practice of occlusion. Carol Stream: Quintessence, 1997. p. 421-434.

42. ZACHRISSON, B. U. latrogenic damage in orthodontic treatment. Part II. J. Clin. Orthod., Boulder, v. 12, no. 3, p. 208-220, Mar. 1978.

\section{Endereço para correspondência}

Roberto Carlos Bodart Brandão

Avenida Américo Buaiz, 501/ 1007 - Torre Norte

Enseada do Suá - Vitória / ES

CEP: 29.050-911

E-mail: rbrandao@99one.com.br 